\title{
Bens afetados às Forças Armadas e o dever de apuração do desvio de seu uso*
}

\author{
Floriano de Azevedo Marques Neto** \\ Marcos Augusto Perez ${ }^{* *}$
}

\section{RESUMO}

Esta opinião legal tem por objetivo analisar em que medida há dever do Estado em apurar desvios no uso de bens afetados às Forças Armadas brasileiras, no período entre as décadas de 1940 e 1980. A Comissão Nacional da Verdade, criada com a finalidade de investigar as violações de direitos humanos praticadas no período da ditadura no Brasil, apurou indícios de que esses bens públicos foram utilizados para a prática de tortura. A conclusão a que chegamos é a de que, tendo em vista os potenciais danos que o desvio no uso dos bens públicos afetados às Forças Armadas para práticas de tortura pode ensejar ao erário, o Estado tem o dever de apurar a responsabilidade por esses desvios e, comprovando-se o dano efetivo ao erário, cobrar regressivamente o agente responsável pelos danos causados.

* Este trabalho foi desenvolvido com o inestimável auxílio da doutoranda Marina Fontão Zago e da mestranda Maís Moreno, ambas do programa de pós-graduação da Universidade de São Paulo (USP). As ideias aqui apresentadas são de exclusiva responsabilidade dos autores, mas este estudo não seria possível sem a participação das duas brilhantes acadêmicas, não apenas na ingente tarefa de pesquisar normas regentes da disciplina de bens e processos administrativos nas Forças Armadas, como na sistematização das informações colhidas para preparação do texto. A elas são gratos os autores.

** Professor titular de direito administrativo da Faculdade de Direito da Universidade de São Paulo (USP).

*** Professor doutor de direito administrativo da Faculdade de Direito da Universidade de São Paulo. 


\section{PALAVRAS-CHAVE}

Bens públicos - desvio no uso afetado - dano ao erário - Forças Armadas - dever de apuração dos indícios - Lei da Anistia - ressarcimento do erário

\section{ABSTRACT}

This legal opinion analyses whether there is (and in which extension) the legal duty for the State to investigate illegal use of public goods destined to the Brazilian Armed Forces, during the 40 to 80's decades. The National Truth Commission (Comissão Nacional da Verdade), created to investigate rights abuses committed during Brazil's military dictatorship, found evidences that these goods assigned to the Armed Forces were used for torture. We argue that, given the potential damage that the illegal use of public goods affected to the Armed Forces for torture may cause to the Treasury, the State has the duty of investigate the liability for these deviations and, in the case effective damage to the treasury occurs, charging the damages from the responsible agent.

\section{KEYWORDS}

Public goods - illegal use - damage to the treasury - Armed Forces duty of ascertaining evidences - Amnesty Law - financial reparations to the treasury

\section{Introdução}

Como ocorre com qualquer outro órgão ou ente público, às Forças Armadas são destinados áreas, prédios públicos e bens diversos necessários para viabilizar a execução de suas competências atribuídas pelo ordenamento jurídico. Para a execução de suas atividades, portanto, elas utilizam-se de bens públicos.

Ocorre que a Comissão Nacional da Verdade, criada pela Lei no ${ }^{2} 12.528$, de 18 de novembro de 2011, com a finalidade de examinar e esclarecer as graves violações de direitos humanos praticadas no período fixado no art. $8^{\circ}$ do Ato das Disposições Constitucionais Transitórias (qual seja, 18 de setembro de 1946 a 5 de outubro de 1988), obteve variados indícios de que, durante as 
décadas de 1940 e até meados da década de 1980, diversos bens destinados ao uso das Forças Armadas foram utilizados para prática de atos ilícitos, inclusive para a prática de tortura. Isto é, em vez de serem utilizados para a execução das atividades institucionais atribuídas às Forças Armadas pelo ordenamento jurídico vigente, esses bens foram usados para a prática de atos outros - não apenas em desconformidade com a destinação legítima desses bens, mas ainda com o gravame de uso para a prática de atos ilícitos ou praticados com abuso de poder. Há indícios, ainda, de que esses bens públicos teriam sido utilizados indevidamente tanto por agentes estatais vinculados às Forças Armadas (militares), como por agentes vinculados a outros entes públicos (agentes civis federais e estaduais).

Nesse cenário, vislumbramos algumas hipóteses para a causa do uso desconforme desses bens públicos. A depender da averiguação acerca dos indícios apurados pela Comissão Nacional da Verdade, será possível concluir que o desvio do uso de bens tenha se dado para a prática de tortura (i) como política de Estado, ordenada expressamente pelos escalões superiores das Forças Armadas no afã de combater o "comunismo", ou as forças contrárias à suposta revolução de 1964; (ii) nas investigações corriqueiras, relacionadas a crimes comuns, sem nenhuma relação com as questões de preservação do golpe de 64 ou do combate ao comunismo internacional; (iii) por grupos radicais dentro das Forças Armadas, contra ordem superior, como afronta aos dirigentes do Estado; ou, enfim, (iv) com finalidades particulares, sem nenhuma relação política. Cada uma dessas situações, se devidamente esclarecidas, podem ter um enfoque diverso sob o prisma do desvio de bens, da responsabilidade civil regressiva e, até mesmo, da aplicação da Lei da Anistia.

Nesse sentido, o presente documento visa a analisar (i) se é devida e possível a abertura de procedimento para a apuração dos indícios de desvios no uso dos bens públicos afetados às Forças Armadas coletados pela Comissão Nacional da Verdade, bem como (ii) o tratamento que deve ser dado à eventual responsabilização dos agentes em função do uso irregular de bens.

Para isso, teceremos breve introdução ao tema dos bens públicos, de modo a discorrer sobre a afetação pública desses e as consequências em caso de eventual uso em desconformidade com sua destinação (tópico II). Em seguida, tais considerações serão aplicadas especificamente no caso dos bens públicos destinados às Forças Armadas, para apresentar as principais balizas do regime jurídico aplicável ao uso de bens públicos afetados e, então, identificar se, diante dos indícios de desvio no uso dos bens públicos afetados 
às atividades das Forças Armadas, é necessária a abertura de procedimento para apurar se houve, de fato, uso desconforme, bem como eventuais responsabilidades por tal desvio (tópico III). Tendo em vista, adiante-se desde já, a conclusão de necessidade de investigação dos indícios de desvio no uso dos bens públicos afetados às Forças Armadas, serão abordadas questões procedimentais, com o escopo de delimitar os meios possíveis para a condução de tais apurações (tópico IV). Após todo o exposto, resumir-se-ão as principais conclusões atinentes à consulta (tópico V).

\section{Nota prévia: a afetação dos bens públicos e suas consequências}

Tendo em vista que o cerne da consulta refere-se à possibilidade (ou, de fato, ao dever) de apuração de indícios de desvio no uso de bens públicos, é necessário abordar, preliminarmente, as regras jurídicas referentes a esse uso.

Será visto que tais regras são definidas a partir do instituto da afetação, que destina o bem ao cumprimento de uma finalidade pública específica.

Como consequência, tem-se o dever de que o referido bem seja utilizado em conformidade com a função que lhe foi atribuída, sendo que eventuais desvios - isto é, uso em desconformidade com a afetação do bem - ensejarão prejuízos ao patrimônio público e à coletividade.

\subsection{A afetação dos bens públicos}

Ao se pretender estudar o regime jurídico que incide sobre o uso dos bens públicos, deve-se abordar o instituto da afetação, que reflete a principal característica dos bens públicos, qual seja, a de serem destinados a uma finalidade pública.

A afetação deve ser entendida como a consagração do bem a uma utilização concernente a uma utilidade pública, ao cumprimento de uma função de satisfação das necessidades gerais da sociedade. É “a atribuição, a um bem público, de sua destinação específica", ${ }_{1}^{1}$ ou ainda a "destinação fática ou jurídica de um bem a uma utilização de interesse público, o que o caracterizará,

1 MEDAUAR, Odete. Direito administrativo moderno. 7. ed. São Paulo: RT, 2003. p. 265. 
conforme o caso, como bem público de uso comum ou bem público de uso especial". 2

Trata-se de noção central para o tratamento jurídico dos bens públicos, independentemente do critério aplicável para sua identificação. Tanto pelo critério de titularidade - que foca a relação de domínio, a partir do titular, do proprietário do bem - , e especialmente na concepção funcionalista dos bens públicos - baseada na utilidade do bem para a coletividade - , a destinação do bem ao cumprimento de uma finalidade pública específica é característica comum a todos os bens públicos - assim considerados seja pelo critério patrimonial, seja pelo critério funcional.

É a afetação que caracterizará, a depender do caso, o bem público como de uso comum, bem público de uso especial, ou até mesmo bem dominical. ${ }^{3}$ Isto é, sempre que o bem do domínio público estiver consagrado ao atendimento de uma necessidade estatal, mesmo que apenas indireta e remotamente aproveitável pela coletividade, haverá uma destinação do bem a um fim público e, portanto, uma afetação genérica. ${ }^{4}$

Em suma, o instituto da afetação implica a subordinação de um bem público a regime jurídico diferenciado, tendo em vista sua destinação à satisfação de necessidades coletivas e estatais. ${ }^{5}$ É a afetação a responsável por habilitar um bem público a um determinado uso, atrelado ao atendimento de uma finalidade pública.

\subsection{O uso dos bens públicos em conformidade com sua afetação}

Se a afetação de um bem público caracteriza-se por lhe imprimir uma destinação específica, consagrando-o permanentemente ao atendimento

2 ARAÚJO, Edmir Netto de. Curso de direito administrativo. São Paulo: Saraiva, 2005. p. 336.

3 Essa é a classificação adotada pelo Código Civil: "Art. 99. São bens públicos: I - os de uso comum do povo, tais como rios, mares, estradas, ruas e praças; II - os de uso especial, tais como edifícios ou terrenos destinados a serviço ou estabelecimento da administração federal, estadual, territorial ou municipal, inclusive os de suas autarquias; III - os dominicais, que constituem o patrimônio das pessoas jurídicas de direito público, como objeto de direito pessoal, ou real, de cada uma dessas entidades".

4 Ou seja, mesmo em havendo bens destinados a uma finalidade patrimonial de interesse geral, em detrimento de uma qualificação de uso comum ou especial, ainda assim estar-se-á diante de afetação, ainda que tida por imprópria. Nesse sentido, MARQUES NETO, Floriano de Azevedo. Bens públicos: função social e exploração econômica. O regime jurídico das utilidades públicas. Belo Horizonte: Fórum, 2009. p. 284.

5 JUSTEN FILHO, Marçal. Curso de direito administrativo. 9. ed. São Paulo: Revista dos Tribunais, 2013. p. 1120. 
de uma finalidade pública, tem-se por claro que, dada a efetiva afetação de determinado bem, ocorre o surgimento de um correlato dever de utilização do referido bem com vistas, justamente, ao cumprimento do fim público a ele consagrado.

Há uma razão para que se proceda à afetação de um bem, razão tal que não pode ser desconsiderada. $\mathrm{O}$ motivo que precede e justifica a afetação de um bem público é a existência de uma finalidade pública cujo cumprimento se faz essencial, de forma que aquele determinado bem afetado corresponda ao instrumento necessário a ser utilizado para que tal finalidade - a ele previamente destinada - seja alcançada. Em outras palavras, o bem público é um meio para o cumprimento de uma função pública, a ele previamente destinada pelo instituto da afetação, o que gera, por consequência, o dever de uso do bem para o alcance da finalidade para a qual foi afetado.

Cumpre ressaltar ser possível - e até mesmo desejável, diante do princípio da eficiência na gestão do patrimônio público - que um bem público seja dotado de afetações múltiplas - isto é, que a utilização de um determinado bem consagre, sempre que possível, mais de uma finalidade. Tem-se que a afetação será múltipla quando o bem comportar usos consagrados distintos, permanentes e compatíveis entre si. ${ }^{6}$

É possível, ainda, que um bem público afetado comporte usos extraordinários, sejam eles excepcionais ou transitórios. ${ }^{7}$ Esses usos devem ser episódicos, seja por implicar uma especial sobrecarga ao uso do bem, seja por ensejar uma interdição temporária do uso afetado, ${ }^{8}$ e não implicam uma nova afetação do bem (vez que a afetação é uma destinação permanente e perene ao bem). A afetação de um bem público, seja ela única ou múltipla, consagra-o a uma finalidade pública de forma permanente e perene. Eventual utilização extraordinária do bem, que venha a impedir sua utilização normal, caracteriza-se pelo fator da temporariedade. Daí se afirmar, ainda, que o uso extraordinário não se confunde com o uso desconforme, contrário à afetação do bem - trata-se, sim, de impedimento temporário à sua utilização normal, devidamente autorizado pelo poder público.

6 É o exemplo típico do uso das vias públicas para a instalação de bancas de jornal, em que, paralelamente à afetação original das vias para a circulação de pessoas, há a afetação secundária para o uso da banca.

7 Exemplo são das vias urbanas destinadas à circulação de veículos mas que podem, excepcional e temporariamente, ser destinadas para uma passeata ou para uma corrida de pedestres. Neste caso, a afetação do bem - circulação de veículos - ficará interditada, porém a título provisório.

8 Marques Neto, Bens públicos, op. cit., p. 286. 
Por fim, destaque-se que, do mesmo modo que a afetação de um bem implica sua consagração a uma dada finalidade, a desafetação refere-se à retirada dessa predisposição, tornando o bem público passível de reafetação a uma finalidade superveniente - aí incluída a finalidade patrimonial caracterizadora dos bens dominicais - ou mesmo possibilitando sua retirada do domínio público. ${ }^{9}$ Tem-se, nesses termos, que a desafetação pode ser compreendida como o desligamento do bem da estrutura institucional e organizacional do Estado. O bem continua a ser público, mas deixa - em princípio - de ser aplicado para o desempenho das funções próprias do Estado, ${ }^{10}$ até que sobrevenha nova finalidade pública a ele consagrada por meio de nova afetação.

Em suma, a afetação deve restar assentada como medida determinante para a delimitação do uso do bem público, de forma a habilitá-lo ao atendimento de uma finalidade pública. Com isso, cria-se um dever ao poder público de utilizar o bem de maneira conforme ao fim público a ele consagrado, sendo certa a possibilidade de responsabilização do poder público caso incorra em utilização desconforme do bem público, conforme se demonstrará a seguir.

\subsection{Potenciais danos ao erário decorrentes do uso desconforme dos bens públicos}

Se a afetação consagra o bem público ao cumprimento de um fim público, tem-se então que o desvio no uso desse bem tende a ensejar um prejuízo a esse fim público. O uso de bem público em desconformidade com sua afetação causa prejuízos à finalidade pública à qual ele está afetado, finalidade essa que visa a efetivar, direta ou indiretamente, interesses da coletividade. Disso decorre que a utilização do bem para finalidade diversa da qual ele está consagrado prejudicará ou até mesmo impedirá o alcance dos interesses públicos visados com uma determinada afetação, podendo ainda trazer outros prejuízos para a coletividade e potenciais danos ao erário.

Importante aqui diferenciar o uso desconforme (isto é, o desvio do uso ao qual está afetado) de duas outras situações diversas: (i) o uso extraordinário e anormal do bem público, previamente autorizado, e (ii) novo uso conferido ao bem, decorrente de uma nova afetação.

9 Ibid., p. 287-288.

10 Justen Filho, Curso de direito administrativo, op. cit., p. 1122. 
No primeiro caso, foi visto no item anterior que o bem pode, excepcionalmente, ser destinado a uso diverso do afetado. Tratar-se-á de um uso extraordinário, anormal e que, caso impeça o uso normal do bem, deverá ser necessariamente temporário. Não há de se falar em prejuízos ao interesse público, uma vez que o uso extraordinário foi precedido de uma outorga prévia, onde o ente titular do bem público autorizou aquele uso diverso, em caráter extraordinário.

Também não se pode falar em uso desconforme do bem público caso a utilização esteja embasada numa nova afetação do bem (um novo fim a ser permanentemente atribuído ao bem), que existirá (i) concomitantemente à afetação anterior (afetação múltipla do bem) ou (ii) isoladamente, após a desafetação do uso anterior.

O uso desconforme é, então, aquele que não coincide com a afetação do bem ou não esteja embasado numa outorga prévia de uso extraordinário. São casos em que há desvio no uso adequado do bem, para o atendimento de fins diversos daqueles relacionados aos interesses públicos para os quais o bem está afetado. Nesse caso, geram-se prejuízos diretos e indiretos à coletividade, na medida em que se desvirtua a função definida para o bem.

Cumpre, aqui, citar ementa de recente acórdão do Superior Tribunal de Justiça (STJ), que trata sobre o uso desconforme de bem público - um desvio da função atribuída ao bem público, que enseja prejuízos aos interesses públicos e gera responsabilização do agente causador do desvio:

EMENTA: RECURSO ESPECIAL. AÇÃO POPULAR E AÇÃO CIVIL PÚBLICA POR ATO DE IMPROBIDADE ADMINISTRATIVA. ARTIGOS 9, CAPUT E INCISO XII, E 11, CAPUT, DA LEI № 8.429/1992. PRESIDENTE DA CÂMARA MUNICIPAL DE VEREADORES. VEÍCULO OFICIAL. UTILIZAÇÃO EM PASSEIOS COM A FAMÍLIA E EM TRANSPORTE DE RAÇÃO PARA CAVALO DE PROPRIEDADE DO AGENTE POLÍTICO. REGULAMENTAÇÃO INTERNA DA CÂMARA. AUSÊNCIA. IRRELEVÂNCIA.

1. As ações popular e civil pública foram propostas contra agente político que, comprovadamente, utilizou veículo oficial em passeios com pessoas da família e em transporte de ração para cavalo de sua propriedade.

2. A eventual ausência de disciplina específica no âmbito da Câmara de Vereadores no tocante ao uso dos bens públicos não garante ilimitados direitos aos agentes políticos respectivos. Ao contrário, no direito 
público brasileiro, os agentes públicos e políticos podem fazer somente o que a lei - em sentido amplo (leis federais, estaduais e municipais, Constituição Federal, etc.) - permite, não aquilo que a lei eventualmente não proíba de modo expresso. Assim, a possível falta de regulamentação implica adotar as restrições próprias e gerais no uso dos bens públicos, os quais se destinam, exclusivamente, a viabilizar atividades públicas de interesse da sociedade. No caso, o veículo recebido destina-se a auxiliá-lo na representação oficial da Casa por ele presidida, comparecendo a eventos oficiais, reuniões de interesse público, localidades atingidas por calamidades públicas e que precisam de ajuda da municipalidade, etc. Flagrantemente, não estão incluídos passeios com a família fora do expediente, em fins de semana e feriados, e transporte de ração para cavalo de propriedade do parlamentar. Nesses últimos exemplos há um induvidoso desvio de poder, considerando que o bem de propriedade pública foi utilizado com finalidade estranha ao interesse público, distante do exercício da atividade parlamentar. (STJ, Recurso Especial no 1.080.221 - RS, relator ministro Castro Meira, j. 7-5-13)

Tem-se então que os bens públicos fazem parte do patrimônio público e devem ser utilizados para o alcance de fins públicos, mais especificamente para o fim para o qual foram afetados. ${ }^{11}$ Com o desvio do uso, há potenciais danos aos interesses coletivos, ao patrimônio público e ao erário, sob quatro enfoques diversos.

Um, o potencial de dano ao interesse público ao qual o bem está afetado. Isto é, (i) se o bem público é afetado para o cumprimento de um fim público específico e (ii) se há desvio no uso afetado do bem, pode-se ter por consequência que (iii) o fim público ao qual o bem está afetado pode ser prejudicado, ensejando danos para os beneficiários diretos desse fim e para toda a coletividade (como destinatária final das atividades prestadas pelo Estado).

11 Nesse sentido: “Temos conosco que a afetação é uma decorrência do princípio da função. Todos os recursos (materiais, humanos e financeiros) do Estado só têm razão de ser se prestantes ao atendimento (direto ou indireto, imediato ou remoto) de uma necessidade coletiva. Caso contrário, a utilização dos recursos estatais implicaria em retirar riqueza da sociedade para imobilizá-la na pessoa jurídica política, esvaziando-a de utilidade. A afetação importa, então, em incorporar o bem ao cumprimento de uma função de interesse geral, de incumbência do poder público" (Marques Neto, Bens públicos, op. cit., p. 345). 
Quanto aos danos causados à coletividade pelo uso do bem público em dissonância a sua afetação, veja-se alguns exemplos que indicam mais concretamente tais prejuízos. No caso de um parque público, temos um bem público de uso comum, que pode ser utilizado por toda a coletividade, em conformidade com regras que asseguram a convivência e fruição por todos. Eventual desvio no seu uso - por exemplo, o fechamento do parque para a realização de uma festa pessoal e particular de um agente público - impedirá a fruição desse espaço pelo público em geral, com prejuízos para toda a coletividade.

Outro exemplo seria o caso de desvio no uso de um hospital público, bem de uso especial afetado para a prestação de serviços públicos de saúde à população. Caso o hospital passe a ser, parcial ou totalmente, utilizado indevidamente para hospedagem de servidores ou seus familiares, haverá prejuízo aos usuários diretos dos serviços do hospital, bem como a toda a coletividade, como potencial usuária desses serviços.

Última hipótese seria o desvio no uso de prédio destinado à instalação de uma repartição pública. Trata-se de um bem de uso especial, afetado à execução das atividades a serem executadas pelo referido órgão. $\mathrm{O}$ emprego deste bem como depósito ou como bem dominical dado em comodato a particulares acarretará prejuízo direto às atividades públicas desenvolvidas no prédio e, indiretamente, à coletividade destinatária desses serviços.

Em todos esses exemplos, o uso diverso ao qual o bem estava afetado enseja prejuízos diretos aos usuários potenciais desses bens e, indiretamente, a toda a coletividade, como destinatária final das atividades estatais. Ao dificultar ou impedir o uso afetado do bem público, obsta-se que ele cumpra sua função como instrumento para a satisfação dos interesses públicos para os quais foi consagrado.

Dois, o possível dano ao patrimônio público decorrente do uso indevido e eventualmente gratuito de um bem público - uso esse que não representa (pelo contrário, pode até prejudicar) o interesse público ao qual o bem está afetado. Isto é, para além do prejuízo ao interesse representado pelo uso afetado ao bem, há também uma possível lesão ao patrimônio público decorrente de sua utilização indevida e gratuita para fins diversos a sua afetação. Lembramos aqui que se deve sempre buscar extrair utilidades dos bens públicos, incluída aí a retributividade econômica de seu uso. ${ }^{12}$

12 Ver, neste sentido, ibid. 
Três, a possibilidade de danos e exigência de responsabilização do Estado que o novo uso pode, ele próprio, gerar. É certo que o novo uso será indevido sob o viés da afetação do bem público, uma vez que se trata de uso desconforme com a afetação do bem. Mas a utilização indevida do bem público pode se prestar a uma atividade que pode ensejar, ela própria, responsabilidades do Estado perante a coletividade. Assim, ao desviar o uso do bem público para a execução de atividades diversas a sua afetação e que podem, elas próprias, ensejar responsabilização do Estado por eventuais danos causados, tem-se outra possibilidade de dano ao erário.

Quatro, a possibilidade de que o novo uso, quando ilícito e reprovável, enseja danos morais ao Estado. A possibilidade de o Estado sofrer dano moral trata-se de uma tese defendida pelo Ministério Público, e que tem sido reconhecida pela jurisprudência. Nesse sentido, há jurisprudência firme no sentido de entender possível às pessoas jurídicas estatais sofrer - paralelamente a danos materiais - danos morais, ensejando o dever de compensação pelo seu causador. ${ }^{13}$ Respalda essa orientação, inclusive, a Súmula no 227 do STJ, uma vez que, não discriminando sua redação entre a personalidade pública ou privada do ente, faz o Poder Judiciário com que incida sobre casos envolvendo tanto pessoas estatais quanto particulares. ${ }^{14}$ Segundo a jurisprudência, as condutas que causam dano moral às pessoas jurídicas estatais - de direito público ou privado - são aquelas (i) de que decorram significativo desprestígio, mácula à imagem do ente perante a sociedade, dificultando sua ação e a consecução de seus fins; ou (ii) que ofendam severamente a coletividade que seja sua titular, no que toca a valores ou sentimento comuns. Evidentemente, tais gravames devem ser comprovados, ultrapassando ademais a mera insatisfação com o desempenho da pessoa jurídica em questão. ${ }^{15}$

13 Nesse sentido: STJ, REsp no 960.926/MG, 2a T., rel. min. Castro Meira, j. 18-3-08; STJ, REsp

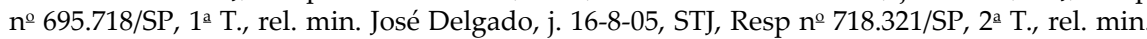
Mauro Campbell Marques, j. 10-11-09; TRF 1, Ap. nº 200334000420322, 3a T., rel. juiz federal Guilherme Mendonça Doehler, j. 2-9-11; TRF 1, Ap. no 199938000183763 , 4a T., rel. juiz Guilherme Doehler, j. 16-1-06; TRF 3, AI. no 0031576-11.2008.4.03.0000, rel. des. Carlos Muta, j. 3a T., j. 15-7-10. Entendendo possíveis os danos morais, mas afastando sua ocorrência no caso concreto em razão da ausência de sua demonstração: STJ, EDREsp no 895.530/PR, 1a T., rel. min. Luiz Fux, j. 14-4-09; TRF 1, Ap. 200436000018903, 3ㄹ T., rel. juiz Tourinho Neto, j. 9-10-09; TRF 3, Ap. no 0006786-54.2003.4.03.6105 (reexame necessário), 6 ª T., rel. des. Consuelo Yoshida, j. 14-6-13; TRF 3, Ap. 0005442-78.2007.84.03.6111, 3ㄹ T., rel. juiz Valdeci dos Santos, j. 27-4-12; TRF 5, Ap. no 465511, 2a T., rel. des. Francisco Wildo, j. 18-2-10.

14 Súmula 227, STJ: "A pessoa jurídica pode sofrer dano moral".

15 A propósito do assunto, cabe reproduzir o voto do ministro Castro Meira nos autos do recurso especial no 960.926/MG: “Esta Corte de Justiça pacificou a sua jurisprudência, reconhecendo 
Em todos esses casos, deve-se ressaltar que o uso desconforme traz, mais do que prejuízos ao interesse público afetado, um potencial de dano ao erário, em razão de (i) eventual dano ao bem público em si, (ii) como por eventual responsabilização do Estado pela não disponibilização à coletividade (ou disponibilização parcial) do fim ao qual o bem está afetado, por (iii) eventual responsabilização do Estado ou decorrente do novo uso indevidamente (pois desconforme à afetação) atribuído ao bem ou, ainda, (iv) em razão de eventuais danos morais que o Estado venha a sofrer pelo novo uso que for (indevidamente) atribuído ao bem.

Destarte, caso o uso desconforme tenha gerado efetivo dano a outrem, ensejará inclusive a responsabilização do Estado perante os cidadãos e a coletividade. É dizer que o Estado pode ser chamado para ressarcir eventuais danos causados aos cidadãos pelo uso desconforme do bem público, que deveria ser instrumento para o cumprimento de uma função pública específica - função essa depreciada pelo uso desconforme do bem. Tal responsabilidade residirá caso o desvio do bem enseje ao menos um dos três possíveis danos acima mencionados: (i) prejuízo ao fim público ao qual o bem está afetado, (ii) dano ao patrimônio público decorrente do uso indevido e eventualmente gratuito de um bem público e (iii) eventuais danos (e consequente responsabilização estatal) gerados em decorrência do novo uso que foi (indevidamente) conferido ao bem.

Ademais, não poderá o Estado exonerar-se dessa responsabilização, alegando que o uso indevido foi causado por ato de agente estatal. Como sabido, a responsabilidade do Estado perante seus administrados é objetiva, cabendo a ele responder, independentemente de dolo ou culpa, por danos que sejam causados pela ação estatal. Eventual responsabilização do agente causador do dano poderá ser posteriormente pleiteada pelo Estado, e a relação entre Estado e agente não pode obstar o pleito do cidadão em responsabilizar o Estado.

Em que pese a possibilidade de responsabilização objetiva do Estado perante a coletividade $-\mathrm{e}$, nesse caso, a ocorrência de dano efetivo ao erário

a possibilidade de dano moral contra pessoa jurídica, nos termos da Súmula 227 (...) Nada justifica a exclusão da pessoa jurídica de direito público não se diga, entretanto, que qualquer ato ímprobo leve a tal dano, há de se ter em mente que ele deve ser aferido no caso concreto, pois não é a mera insatisfação da coletividade com falta de realização do ideal do Estadoprovedor ou mesmo a simples indignação que se reflita na coletividade que justificaria sua existência. O Magistrado deve ter como foco as consequências do ato e, com base nas argumentações e provas trazidas aos autos, nortear a aferição de existência e o grau do dano para efeito de cálculo da indenização". 
- por danos decorrentes do uso desconforme dos bens públicos, é possível que o Estado requeira a responsabilização do agente causador (dolosa ou culposamente) do uso indevido do bem público.

Ao causar o desvio do uso afetado de um bem que integra o patrimônio público, o agente estatal pratica um ilícito que ensejar danos ao erário. ${ }^{16}$ O Estado, por sua vez, pode então requerer que o agente estatal repare os prejuízos causados ao erário pelo ilícito pelo qual foi responsável (desvio no uso de bem público). Dessa forma, o agente que tenha, com dolo ou culpa, desviado o uso afetado do bem, utilizando-o para outro fim diverso do que lhe foi afetado, deve ser responsabilizado tanto pelos prejuízos causados ao erário e à coletividade (ressarcindo-os desses danos), como, eventualmente, administrativa e penalmente, conforme a legislação aplicável ao agente e as circunstâncias fáticas. ${ }^{17}$ Sobre a possibilidade de o Estado requerer o ressarcimento por danos causados por seus agentes, cite-se, exemplificativamente, os seguintes acórdãos:

CONSTITUCIONAL. RESPONSABILIDADE CIVIL DO ESTADO. ATO DO AGENTE PÚBLICO: GOVERNADOR. C.F., art. 37, §6으 - No caso, o ato causador de danos patrimoniais e morais foi praticado pelo Governador do Estado, no exercício do cargo: deve o Estado responder pelos danos. C.F., art. $37, \S 6^{\circ}$ II - Se o agente público, nessa qualidade, agiu com dolo ou culpa, tem o Estado ação regressiva contra ele (C.F., art. 37, §6º). III - R.E. inadmitido. Agravo não provido. (STF, AI no 167.659/PR, 2a T., rel. min. Carlos Velloso, j. 18-6-96)

16 O desvio do uso afetado, ao ensejar dano ao patrimônio público, enquadra-se na definição de ato ilícito trazida tanto pelo Código Civil vigente à época dos fatos (Lei no 3.071/1916), como pelo Código Civil atualmente vigente (Lei no 10.406/2002). Nesse sentido:

Código de 1916: “Art. 159. Aquele que, por ação ou omissão voluntária, negligência, ou imprudência, violar direito, ou causar prejuízo a outrem, fica obrigado a reparar o dano. A verificação da culpa e a avaliação da responsabilidade regulam-se pelo disposto neste Código, arts. 1.521 a 1.532 e 1.542 a $1.553 . "$.

Código de 2002: “Art. 186. Aquele que, por ação ou omissão voluntária, negligência ou imprudência, violar direito e causar dano a outrem, ainda que exclusivamente moral, comete ato ilícito".

17 Veja-se que, atualmente, o desvio no uso de bens públicos é inclusive enquadrado como ato de improbidade administrativa, conforme previsto no art. 10, caput, Lei no 8.429/1992 (Lei de Improbidade Administrativa), literalmente: "Art. 10. Constitui ato de improbidade administrativa que causa lesão ao erário qualquer ação ou omissão, dolosa ou culposa, que enseje perda patrimonial, desvio, apropriação, malbaratamento ou dilapidação dos bens ou haveres das entidades referidas no art. 1ำ desta lei, e notadamente: (...)". 
PROCESSUAL CIVIL - RESPONSABILIDADE CIVIL DO ESTADO - AÇÃO DE INDENIZAÇÃO POR DANOS MORAIS - PRISÃO ILEGAL - ATO ILÍCITO PRATICADO POR AGENTE PÚBLICO ABUSO DE AUTORIDADE - DENUNCIAÇÃO À LIDE - DIREITO DE REGRESSO - VIOLAÇÃO DOS ARTS. 165, 458 E 535 DO CPC: INEXISTÊNCIA. 1. Os embargos de declaração devem apresentar razões que estejam correlatas com os pontos indicados como omissos ou contraditórios do recurso especial, a pretexto de violação do art. 535 do CPC, sob pena de inovação na lide. 2. Inexistindo omissão ou contradição, e estando bem fundamentado o acórdão, afasta-se a alegação de contrariedade aos arts. 165, 458 e 535 do CPC. 3 . O direito de regresso fica garantido ao Estado na medida em que reconhece tenha o agente público agido com dolo. 4 . Recurso especial improvido. (STJ, REsp no 782.834/MA, 2a T., rel. min. Eliana Calmon, j. 20-3-07)

PROCESSUAL CIVIL. ADMINISTRATIVO. RESPONSABILIDADE CIVIL OBJETIVA. PLEITO DE DANOS MORAIS. INDEPENDÊNCIA DAS AÇÕES PROPOSTAS CONTRA O ENTE OU ENTIDADE PÚBLICA E A AÇÃO DE REGRESSO. INTERESSE PROCESSUAL QUE SE MANTÉM MESMO QUANDO AFASTADA EVENTUAL RESPONSABILIDADE DO FUNCIONÁRIO PÚBLICO. RETORNO DOS AUTOS QUE SE IMPÕE PARA JULGAMENTO DA AÇÃO CONTRA O CONSELHO PROFISSIONAL, QUE RESPONDE OBJETIVAMENTE POR SEUS ATOS. (...) 3. A responsabilidade civil do Estado objetiva nos termos do art. $37, \S 6^{\circ}$ da Constituição Federal, não se confunde com a responsabilidade subjetiva dos seus agentes, perquirida em ação regressiva ou ação autônoma. 4. Extrai-se da Constituição Federal de 1988 a distinção entre a possibilidade de imputação da responsabilidade civil, de forma direta e imediata, à pessoa física do agente estatal, pelo suposto prejuízo a terceiro, e o direito concedido ao ente público de ressarcir-se, mediante ação de regresso, perante o servidor autor de ato lesivo a outrem, nos casos de dolo ou culpa. (STJ, REsp no 976.730/RS, 1a T., rel. min. Luiz Fux (rel. para acórdão), j. 24-6-08)

Importante observar ainda que o Estado, por meio da autoridade competente, tem o dever de apurar as responsabilidades pelo uso desconforme, por duas razões principais. Primeiro porque houve um desvio no uso afetado, 
que pode ensejar prejuízos ao patrimônio público e à coletividade. Segundo porque o Estado pode ser efetivamente responsabilizado por esse desvio, o que igualmente ensejará prejuízos concretos ao Erário. Intensifica-se, assim, a necessidade de que o Estado, por meio de autoridade competente, apure a conduta de seu agente. Tendo em vista os prejuízos gerados pelo uso desconforme do bem público e sua possível responsabilização, o Estado deve investigar a conduta indevida de seu agente estatal.

Pelo até aqui exposto, é possível concluir que: (i) a característica essencial aos bens públicos é estarem eles afetados a um fim público, a uma função pública específica; (ii) a afetação enseja o dever de utilização dos bens públicos em conformidade com a função pública a eles atribuída; (iii) o uso desconforme pode gerar prejuízos ao patrimônio público (uma vez que bens públicos são utilizados em desconformidade com sua função) e à coletividade (uma vez que a função pública para a qual os bens públicos deveriam servir deixa de ser atendida); (iv) esses prejuízos podem gerar a responsabilização de reparação, pelo Estado, perante a coletividade, causando efetivo dano ao erário; e (v) diante desses potenciais danos ao erário, é dever do Estado apurar eventuais desconformidades no uso de bens públicos afetados, de modo a identificar responsabilidades por tal ilícito.

\section{O uso de bens públicos pelas Forças Armadas: indícios de desvios e danos ao erário}

Abordados os aspectos jurídicos gerais referentes aos fins públicos para os quais os bens públicos estão afetados - e, especialmente, as consequências do uso desconforme com esses fins -, passa-se agora a analisar o uso de bens públicos pelas Forças Armadas.

O objetivo será, inicialmente, identificar qual o regime jurídico incidente sobre o uso desses bens, bem como eventuais consequências em caso de uso desconforme - atentando-se para eventuais especificidades da legislação vigente à época dos indícios de desvio no uso (período compreendido entre as décadas de 1940 e 1980).

Em seguida, será visto que os indícios no desvio de uso de bens públicos afetados às Forças Armadas para práticas de tortura já têm gerado (e deverão continuar gerando) danos ao erário, sendo então devida a apuração das responsabilidades por esses desvios. 


\subsection{0 uso afetado às atividades prestadas pelas Forças Armadas}

À época dos fatos analisados, as (então denominadas) Forças Armadas (formadas pela Marinha de Guerra, Exército e Aeronáutica Militar) tinham suas finalidades fixadas pela Constituição Federal de 1946 (art. 176 e seguintes), pela Constituição Federal de 1967 (art. 92 e seguintes, antes da Emenda Constitucional no 1/1969), e regulamentadas pelos Decreto-Lei no 3.084/1941, Decreto-Lei no 200/1967, Decreto nº 64.775/1969, Decreto nº 79.031/1976 e Decreto no ${ }^{-} 87.737 / 1982$.

Esses normativos estabeleciam como objetivo principal das Forças Armadas a proteção da pátria e da ordem interna, conforme as competências específicas de cada uma delas.

Para a execução das atividades necessárias ao cumprimento das finalidades alocadas às Forças Armadas, foram disponibilizados diversos instrumentos e ferramentas, dentre os quais o uso de bens públicos. Os bens públicos utilizados para as atividades do Exército, da Marinha e da Aeronáutica passaram a estar afetados ao cumprimento dos fins dessas Forças, tornam-se um dos meios necessários para a execução de suas atividades-fim. Em outras palavras, com sua destinação ao uso das Forças Armadas, os bens públicos passaram a estar afetados aos serviços prestados pelos órgãos da defesa nacional.

Especificamente em relação aos bens públicos federais, ${ }^{18}$ tal relação era essencialmente regulada pelo Decreto-Lei n ${ }^{\circ}$ 9.760/1946, ${ }^{19}$ que disciplinou a gestão dos imóveis da União.

De acordo com o diploma, caberia à Secretaria do Patrimônio da União (SPU) a administração geral dos bens públicos federais. Estes poderiam ter duas destinações principais: (i) ser utilizados em serviço público, assim considerados os ocupados por serviço ou servidor federal (art. 76); ${ }^{20}$ ou (ii) caso não ocupados em serviço público, ser alugados, aforados ou cedidos (art. 64)..$^{21}$

18 A legislação aqui analisada restringiu-se ao âmbito federal. Ainda assim, entende-se que as conclusões aqui tecidas aplicam-se igualmente a bens públicos estaduais e municipais, bem como a bens privados, que tenham sido afetados ao uso das Forças Armadas.

19 Ressalte-se que tal diploma permanece vigente até hoje, com algumas alterações. No presente documento, serão utilizadas as disposições então vigentes à época dos fatos, com expresso apontamento quando houver alterações anteriores ou posteriores.

20 "Art. 76. São considerados como utilizados em serviço público os imóveis ocupados: I - por serviço federal; II - por servidor da União, como residência em caráter obrigatório."

21 "Art. 64. Os bens imóveis da União não utilizados em serviço público poderão, qualquer que seja a sua natureza, ser alugados, aforados ou cedidos. (....)" 
Se a administração geral do patrimônio imobilizado da União competia à SPU, quando utilizados em serviço público os bens passavam a ser administrados e geridos pelos órgãos e repartições responsáveis por tal uso. Nesse sentido era a disposição do art. 77, do Decreto-Lei no 9.760/1946: “Art. 77. A administração dos próprios nacionais aplicados em serviço público compete às repartições que os tenham a seu cargo, enquanto durar a aplicação. Cessada esta, passarão esses imóveis, independentemente do ato especial, à administração do S.P.U”.

O Decreto-Lei oㅜ 9.760/1946 preocupou-se, ainda, em assegurar a eficiência na utilização dos bens federais, determinando que apenas os bens estritamente necessários para a prestação dos serviços fossem a eles afetados. ${ }^{22}$

A partir dessa legislação vigente à época, tem-se então que os bens públicos federais ocupados e utilizados pelas Forças Armadas estavam afetados às atividades-fim das Forças, e, pois, sob sua gestão e administração, conforme art. 76, inciso I, combinado com art. 77, ambos do Decreto-Lei no 9.760/1946.

Assim, as Forças poderiam utilizar-se dos bens federais que fossem necessários para que ela executasse suas atividades. Afinal, tais bens foram afetados à execução dos serviços e das atividades a serem prestadas pelas Forças Armadas. Em outras palavras, os interesses públicos a que esses bens públicos federais estavam vinculados equivaliam aos fins atribuídos às Forças Armadas pelo ordenamento jurídico então vigente, servindo de instrumento para que esses entes cumprissem suas atividades-fim.

Ao mesmo tempo que os bens públicos federais estavam afetados aos serviços prestados pelas Forças Armadas e podiam (de fato, deviam) ser por ela utilizados, por outro lado caberia também às Forças gerir e administrar tais bens. Sob a administração das Forças Armadas, era seu dever gerir, de forma eficiente, o patrimônio da União, assegurando que os bens públicos fossem utilizados para o alcance dos fins públicos a eles afetados. Se lhe foi cedida a gestão de determinados bens públicos federais - bens que, por serem públicos, devem sempre atender aos interesses públicos - , era dever das Forças Armadas garantir que os bens fossem utilizados justamente para o alcance dos fins para os quais eles lhes foram cedidos.

22 Nesse sentido, dispunha o art. 78, do citado diploma: "Art. 78. O S.P.U. velará para que não sejam mantidos em uso público ou administrativo imóveis da União que ao mesmo uso não sejam estritamente necessários, levando ao conhecimento da autoridade competente as ocorrências que a esse respeito se verifiquem". 
Trata-se, de fato, do dever de assegurar a boa gestão do patrimônio público, ao qual todos órgãos e entidades que gerem bens públicos estão obrigados. Conforme visto no tópico anterior, todo bem público deve atender a um fim público. Por vezes, o bem poderá atender a diversos fins públicos, de forma excludente ou não. Por exemplo, um imóvel para a instalação de uma repartição pública pode ser destinado, em princípio, à instalação de diferentes repartições públicas - escola, hospital, prédio administrativo de diferentes secretarias etc. -, e em qualquer caso o imóvel atenderá a interesses públicos. Entretanto, ao ser afetado a uma destinação específica, o imóvel deve ser administrado pelo órgão responsável, que deverá resguardar o cumprimento da finalidade atribuída ao órgão. Se o bem não for imprescindível para essa finalidade, deve ser devolvido ao órgão responsável pela administração dos imóveis, para que seja afetado a outro uso público.

No caso, os bens eram afetados aos serviços prestados pelas Forças Armadas. Presume-se, ainda, que todos esses bens eram essenciais para a execução das competências das Forças Armadas (assim compreendidas aquelas previstas na regulamentação aplicável) - pois, do contrário, deveriam ter sido devolvidos à SPU, conforme determinação constante no art. 77, Decreto-Lei no 9.760/1946. Afetados a esses fins, caberia então às Forças Armadas, como ente responsável pela administração desse patrimônio federal, assegurar seu uso conforme.

Destarte, a afetação de bens públicos aos serviços prestados pelas Forças Armadas enseja duas principais consequências. Uma, as Forças passam a ter o direito de uso sobre esses bens, para que possam executar suas atividades, utilizando-se, para isso, dos bens públicos afetados a elas. Duas, as Forças passam a ter o dever de administrar tais bens, assegurando o uso conforme sua afetação - qual seja, o alcance dos fins atribuídos às Forças Armadas.

\subsection{Consequências em caso de desvio no uso dos bens públicos afetados às Forças Armadas}

Ao serem afetados ao uso das Forças Armadas, os bens públicos passaram a ser destinados, dentre os diferentes interesses públicos que poderiam atender, especificamente à viabilização das atividades-fim das Forças Armadas. Apenas os bens estritamente necessários para a prestação de um determinado serviço público podem ser a eles afetados. Mas, uma vez 
delimitada tal afetação, esses bens devem ser utilizados em conformidade com essa função que lhe foi destinada.

As Forças Armadas têm, então, o dever de gerir esse patrimônio público de forma a assegurar sua destinação.

Nesse contexto, o uso desconforme dos bens afetados às Forças Armadas - assim entendido como o uso diverso da função para a qual estão afetados, e que não esteja pautado numa outorga de uso extraordinário - gera prejuízos diretos a suas atividades (uma vez que se trata de bens imprescindíveis para prestá-las) e indiretos à coletividade (na medida em que dificulta ou obsta o cumprimento dos fins públicos a serem alcançados pelas Forças Armadas, ou ainda que pode trazer danos ao erário). Pois, se os bens eram imprescindíveis para o alcance do fim afetado, tem-se por certo que o uso para fim diverso certamente dificultará ou até mesmo prejudicará o alcance desse fim público. Se, por exemplo, um determinado terreno é afetado às Forças Armadas porque considerado essencial para o controle territorial tendo em vista sua localização estratégica, certamente o uso desse terreno para fins outros causará prejuízo ao controle territorial, cuja execução compete às Forças Armadas. ${ }^{23}$

Conforme visto no tópico anterior, eventual uso desconforme do bem público pode ensejar danos diversos que, se concretados, ensejam a responsabilização do Estado e causam, portanto, prejuízos ao erário.

Em outras palavras, o uso dos bens públicos afetados às Forças Armadas para finalidades diversas às relacionadas aos fins desses entes pode causar (i) prejuízos às atividades das Forças Armadas (tendo em que o bem foi desviado das atividades das Forças), (ii) danos ao patrimônio público, uma vez que os bens públicos que deveriam estar destinados às atividades das Forças Armadas passam a ser usados para fins diversos, possivelmente sem qualquer ressarcimento ao gestor do bem por tal uso; e (iii) danos em decorrência do novo uso que foi (indevidamente) conferido aos bens afetados às Forças Armadas, seja em razão de eventual necessidade de o Estado responsabilizar-se por danos (materiais e morais) causados pelo novo uso (ensejando, pois, danos ao erário), seja por eventuais danos morais causados ao próprio Estado pelo novo uso.

23 Ressalte-se ainda que dano à função atribuída ao bem ocorrerá independentemente do uso desconforme que seja a ele conferido. Assim, por exemplo, ainda que o terreno seja faticamente utilizado para a instalação de um hospital público (uso que pode trazer benefícios à coletividade) sem que haja uma afetação a essa finalidade (o que é essencial para a caracterização do uso desconforme), ainda assim haverá prejuízo para o fim ao qual o bem está destinado, qual seja, o uso para as atividades das Forças Armadas. 
Ocorrido o desvio no uso dos bens públicos afetados às Forças Armadas e verificado um dos danos acima mencionados, o Estado poderá ser responsabilizado perante a coletividade. Isto é, o Estado poderá ser cobrado por qualquer cidadão pelos prejuízos ensejados à função pública afetada ao bem usado em desconformidade. Isso significa que quaisquer danos que tenham sido gerados pelo uso desconforme dos bens afetados às atividades das Forças Armadas deverão ser ressarcidos pelo Estado, independentemente de existência de eventual culpa ou dolo do agente estatal causador desse desvio. A responsabilidade do Estado diante de eventuais danos causados pelo uso desconforme de bens públicos é, conforme visto, objetiva, cabendo ao Estado ressarcir todos os prejuízos verificados, conforme o caso concreto.

Contudo, apontou-se também que o uso desconforme poderá ensejar a responsabilização do agente estatal causador do desvio do uso afetado perante o Estado, em razão do dano ao patrimônio público decorrente do uso desconforme. Os bens públicos afetados às Forças Armadas eram essenciais para a execução das competências determinadas pelo ordenamento jurídico vigente. Se esses bens foram utilizados para a execução de fins outros, então o agente estatal responsável por esse desvio causou prejuízos diretos às Forças Armadas e indiretos à coletividade, devendo ser cobrado por isso. O Estado, por meio da autoridade estatal responsável, tem o dever de averiguar a conduta do agente estatal que causou o uso desconforme do bem e responsabilizá-lo pelos prejuízos causados, sem prejuízo de aplicação de outras sanções (civis, administrativas ou mesmo penais) eventualmente incidentes sobre o caso concreto.

\subsection{Caso concreto: os indícios de desvio do uso e os potenciais danos ao erário}

Conforme apontado, durante os trabalhos da Comissão Nacional da Verdade foi recolhido vasto material com indícios de que bens públicos destinados à execução das atividades das Forças Armadas teriam sido utilizados para prática de atos de tortura, no período compreendido entre 18 de setembro de 1946 e 5 de outubro de 1988. Esses bens teriam sido desviados para a prática de tortura por agentes estatais vinculados tanto às Forças Armadas (militares), como a outros entes públicos (agentes civis federais e estaduais). 
Adotando esta hipótese de trabalho, tem-se que os bens teriam sido utilizados pelos servidores militares e em outras circunstâncias por agentes civis sequer vinculados às Forças Armadas. Utilização essa não apenas em desconformidade com a sua destinação legal, mas ainda com o gravame de uso para a prática de atos ilícitos de abuso de poder, já que não se tem conhecimento de norma que, no período da ditadura militar, autorizasse a tortura, menos ainda mediante o uso de bens públicos.

Tem-se, então, a (i) prática de um ilícito (uso desconforme dos bens públicos afetados às Forças Armadas), que (ii) pode gerar diversos danos ao erário.

Quanto ao primeiro ponto, o ilícito decorre da utilização de bens públicos em desconformidade com seu uso afetado: os bens deveriam ser usados como suporte para as atividades das Forças Armadas, mas foram desviados para a prática de atos de tortura.

De fato, temos por certo que a prática de tortura não se encontrava entre as atividades legalmente atribuídas às Forças Armadas, não podendo ela se enquadrar como parte do uso afetado desses bens. Não havia, no ordenamento jurídico então vigente, norma jurídica legítima que autorizasse a prática de tortura pelas Forças Armadas. Tampouco existia - até onde é de conhecimento público - qualquer ato que formalizasse ou permitisse o uso dos bens públicos afetados às Forças Armadas para práticas de tortura. Pelo contrário: a Lei Federal no 4.898, promulgada no ano de 1965, expressamente enquadrou como abuso de autoridade as práticas que atentassem contra a liberdade de locomoção e à incolumidade física do indivíduo, sujeitando-as à responsabilização administrativa, civil e criminal. ${ }^{24}$

24 Nesse sentido: “Art. 1ํㅡ $\mathrm{O}$ direito de representação e o processo de responsabilidade administrativa civil e penal, contra as autoridades que, no exercício de suas funções, cometerem abusos, são regulados pela presente lei. (...) Art. 3ำ Constitui abuso de autoridade qualquer atentado: a) à liberdade de locomoção; b) à inviolabilidade do domicílio; c) ao sigilo da correspondência; d) à liberdade de consciência e de crença; e) ao livre exercício do culto religioso; f) à liberdade de associação; g) aos direitos e garantias legais assegurados ao exercício do voto; h) ao direito de reunião; i) à incolumidade física do indivíduo; j) aos direitos e garantias legais assegurados ao exercício profissional. Art. 4ํㅡㄴ Constitui também abuso de autoridade: a) ordenar ou executar medida privativa da liberdade individual, sem as formalidades legais ou com abuso de poder; b) submeter pessoa sob sua guarda ou custódia a vexame ou a constrangimento não autorizado em lei; c) deixar de comunicar, imediatamente, ao juiz competente a prisão ou detenção de qualquer pessoa; d) deixar o Juiz de ordenar o relaxamento de prisão ou detenção ilegal que lhe seja comunicada; e) levar à prisão e nela deter quem quer que se proponha a prestar fiança, permitida em lei; f) cobrar o carcereiro ou agente de autoridade policial carceragem, custas, emolumentos ou qualquer outra despesa, desde que a cobrança não tenha apoio em lei, quer quanto à espécie quer quanto ao seu valor; 
Nesse contexto, configura-se como uso ilícito de bens públicos afetados às Forças Armadas tanto sua utilização para práticas de tortura por agentes das Forças Armadas, como a permissão de seu uso para práticas de tortura conduzidas por agentes estatais outros, não vinculados às Forças Armadas. Em ambos os casos, há uso desconforme dos bens (isto é, não convergentes com sua afetação), agravado pelo fato de que o uso desconforme consistia em práticas por si só ilícitas (atos de tortura).

Se é certa a existência de um ilícito decorrente do uso desconforme dos bens públicos afetados às Forças Armadas, é igualmente claro que tal ilícito tem o potencial de ensejar danos ao erário, sob três perspectivas diferentes: (i) pelos possíveis danos ao patrimônio público causados pelo uso desconforme (em prejuízo à afetação) e gratuito de um bem público; (ii) pelos possíveis danos ao erário ensejados em razão da responsabilização do Estado pelo uso desconforme dos bens públicos, isto é, pela possibilidade de o Estado ser cobrado pelos danos materiais e morais causados às vítimas dos atos de tortura praticados nesses bens; e, eventualmente, (iii) pelo possível dano moral do Estado brasileiro, também como decorrência do novo uso atribuído aos bens (práticas de tortura).

Em relação à primeira perspectiva, o uso desconforme e gratuito que foi (irregularmente) conferido ao bem público pode ensejar danos ao patrimônio público (uma vez que o bem público foi utilizado em desconformidade com sua afetação), bem como possível perda de receitas públicas decorrente da não cobrança pelo novo uso conferido. O novo uso interfere na destinação correta do bem, podendo causar prejuízos às atividades de competência das Forças Armadas e, ainda, danos aos próprios bem em caso de incompatibilidade do uso. Além disso, o novo uso não traz qualquer benefício à coletividade pela utilização de um bem público.

Pela segunda perspectiva, o desvio no uso desses bens pode trazer danos ao erário em caso de responsabilização do Estado pelos atos de tortura praticados nesses bens públicos afetados às Forças Armadas.

A tortura (física ou psicológica), sabe-se, é ato ilícito, e sua prática por autoridades passou a ser expressamente caracterizada como abuso de poder a

\footnotetext{
g) recusar o carcereiro ou agente de autoridade policial recibo de importância recebida a título de carceragem, custas, emolumentos ou de qualquer outra despesa; h) o ato lesivo da honra ou do patrimônio de pessoa natural ou jurídica, quando praticado com abuso ou desvio de poder ou sem competência legal; i) prolongar a execução de prisão temporária, de pena ou de medida de segurança, deixando de expedir em tempo oportuno ou de cumprir imediatamente ordem de liberdade".
} 
partir do ano de 1965. Diante disso, é juridicamente viável que um sujeito que tenha sido torturado (ou seus descendentes) pleiteie indenização do Estado, para reparar os danos materiais e morais ensejados pelas práticas de tortura ocorridas durante o período de ditadura. A jurisprudência majoritária tem reconhecido o dever do Estado em reparar economicamente (pelos danos materiais e morais) aqueles que foram torturados durante a ditadura ou os descendentes daqueles que desaparecem nesse período - sendo inclusive imprescritível o direito de pleitear tal reparação. Nesse sentido, citem-se, a mero título exemplificativo, algumas ementas das decisões mais recentes do STJ, que mostram o entendimento claro e inequívoco do Tribunal quanto ao direito de ressarcimento pelos danos materiais e morais das vítimas de tortura durante o período da ditadura militar:

PROCESSUAL CIVIL. ADMINISTRATIVO. INDENIZAÇÃO POR DANOS MORAIS. PERSEGUIÇÃO POLÍTICA OCORRIDA DURANTE O REGIME MILITAR. IMPRESCRITIBILIDADE. INAPLICABILIDADE DO ART. 1ํ DO DECRETO 20.910/1932. PRECEDENTES. ACUMULAÇÃO DE REPARAÇÃO ECONÔMICA COM INDENIZAÇÃO POR DANOS MORAIS. POSSIBILIDADE. PRECEDENTES.

1. A jurisprudência do STJ é pacificada no sentido de que a prescrição quinquenal, disposta no art. $1^{\circ}$ do Decreto 20.910/1932, é inaplicável aos danos decorrentes de violação de direitos fundamentais, que são imprescritíveis, principalmente quando ocorreram durante o Regime Militar, época na qual os jurisdicionados não podiam deduzir a contento suas pretensões.

2. Ressalte-se que a afronta aos direitos básicos da pessoa humana, como a proteção da sua dignidade lesada pela tortura e prisão por delito de opinião durante o Regime Militar de exceção, enseja ação de reparação ex delicto imprescritível e ostenta amparo constitucional no art. $8^{\circ}, \S^{3^{\circ}}$, do Ato das Disposições Constitucionais Transitórias.

3. O STJ entende ser possível cumular o valor recebido a título de reparação econômica com aquele de indenização de danos morais.

4. Não compete ao STJ, em julgamento de Recurso Especial e para fins de prequestionamento, apreciar alegação de afronta a dispositivos constitucionais, sob pena de usurpação da competência do STF (art. 102, III, da CF/1988). 
5. Agravo Regimental não provido. (AgRg no AREsp 266.082/RS, rel. ministro Herman Benjamin, Segunda Turma, julgado em 11-6-2013, DJe 24-6-2013)

Ementa: PROCESSUAL CIVIL. EMBARGOS DE DECLARAÇÃO. OFENSA AO ART. 535 DO CPC NÃO CONFIGURADA. REDISCUSSÃO DA CONTROVÉRSIA. IMPOSSIBILIDADE.

1. Hipótese em que o acórdão embargado consignou que: a) a jurisprudência do STJ é pacificada no sentido de que a prescrição quinquenal, disposta no art. 1ํo do Decreto 20.9101932, é inaplicável aos danos decorrentes de violação de direitos fundamentais, que não prescrevem, principalmente quando ocorreram durante o Regime Militar, época na qual os jurisdicionados não podiam deduzir a contento suas pretensões. Precedentes do STJ; b) ressalte-se que a afronta aos direitos básicos da pessoa humana, como a proteção da sua dignidade lesada pela tortura e prisão por delito de opinião durante o Regime Militar de exceção, enseja ação de reparação ex delicto imprescritível e ostenta amparo constitucional no art. $8^{\circ}, \S^{\circ} 3^{\circ}$, do Ato das Disposições Constitucionais Transitórias; e c) o STJ entende que é possível a cumulação do valor recebido a título de reparação econômica com aquele de indenização de danos morais. Precedentes do STJ.

2. A Turma desproveu o apelo com motivação clara e suficiente, inexistindo omissão, contradição ou obscuridade no acórdão embargado.

3. Os argumentos da embargante denotam mero inconformismo e intuito de rediscutir a questão, não se prestando os aclaratórios a esse fim. 4. Não procede a tese de contrariedade à cláusula de Reserva de Plenário, pois a decisão embargada dirimiu a controvérsia com base na jurisprudência do STJ sobre a temática posta em exame, não tendo declarado a inconstitucionalidade de qualquer dispositivo de lei.

5. Embargos de Declaração rejeitados. (STJ, EDcl no AgRg no AREsp 160.328/RJ, rel. ministro Herman Benjamin, Segunda Turma, julgado em 4-9-2012, DJe 11-9-2012)

PROCESSUAL CIVIL. ADMINISTRATIVO. AGRAVO REGIMENTAL NO RECURSO ESPECIAL. RESPONSABILIDADE CIVIL DO ESTADO. TORTURA. REGIME MILITAR. IMPRESCRITIBILIDADE. DANOS MORAIS. REVISÃO DE VALORES. REEXAME DE 
MATÉRIA FÁTICO-PROBATÓRIA. IMPOSSIBILIDADE. SÚMULA 7STJ. DIVERGÊNCIA JURISPRUDENCIAL. NÃO COMPROVAÇÃO. DESCUMPRIMENTO DOS REQUISITOS LEGAIS. PRECEDENTES DO STJ.

1. Conforme o entendimento jurisprudencial do STJ, em face do caráter imprescritível das pretensões indenizatórias decorrentes dos danos a direitos da personalidade ocorridos durante o regime militar, não há que se falar em aplicação do prazo prescricional do Decreto 20.91032.

2. É pacífico o entendimento desta Corte Superior no sentido de que a quantia estipulada a título de danos morais, quando atende aos critérios de justiça e razoabilidade, não pode ser revista, em razão do óbice da Súmula 7STJ. (...)

4. Agravo regimental não provido. (STJ, AgRg no REsp 1042632/GO, rel. ministro Mauro Campbell Marques, Segunda Turma, julgado em 2-6-2011, DJe 9-6-2011)

Ementa: ADMINISTRATIVO. AGRAVO REGIMENTAL NO RECURSO ESPECIAL. RESPONSABILIDADE CIVIL DO ESTADO. AÇÃO DE INDENIZAÇÃO POR DANOS MORAIS E MATERIAIS. PERSEGUIÇÃO POLÍTICA. DITADURA MILITAR. PRISÃO E TORTURA A INTEGRANTE DO PARTIDO COMUNISTA BRASILEIRO. DANOS CONFIGURADOS. IMPRESCRITIBILIDADE DE PRETENSÃO INDENIZATÓRIA DECORRENTE DE VIOLAÇÃO DE DIREITOS HUMANOS FUNDAMENTAIS DURANTE O PERÍODO DE EXCEÇÃO. ARTIGOS DE LEI APONTADOS COMO VIOLADOS NÃO PREQUESTIONADOS PELO ACÓRDÃO A QUO. SÚMULA 211STJ. QUANTUM INDENIZATÓRIO. ANÁLISE DAS CIRCUNSTÂNCIAS DO CASO CONCRETO. VERBA FIXADA COM RAZOABILIDADE. IMPOSSIBILIDADE DE REVISÃO NA VIA ESPECIAL. SÚMULA 7STJ. PRECEDENTES.

1. O STJ pacificou entendimento no sentido de que são imprescritíveis as ações de reparação de dano ajuizadas em decorrência de perseguição, tortura e prisão, por motivos políticos, durante o Regime Militar. Precedentes: REsp 959.904PR, Rel. Ministro Luiz Fux, Primeira Turma, julgado em 2304/2009, DJe 29/09/2009; AgRg no Ag 970.753MG, Rel. Ministra Denise Arruda, Primeira Turma, julgado em 21/10/2008, 
DJe 12/11/2008; REsp 449.000PE, Rel. Ministro Franciulli Netto, Segunda Turma, julgado em 0506/2003, DJ $3006 / 2003$ p. 195.

2. Os artigos 4 e 16 da Lei n. 10.559/2002 não foram prequestionados no Tribunal de origem, apesar de a parte ter opostos aclaratórios. Incidência da Súmula 211STJ.

3. No pertinente ao quantum indenizatório fixado pela instância a quo, o Superior Tribunal de Justiça consolidou orientação de que a revisão do valor da indenização somente é possível quando exorbitante ou insignificante a importância arbitrada, em flagrante violação dos princípios da razoabilidade e da proporcionalidade.

4. O Tribunal de origem, ao considerar as circunstâncias do caso concreto, as condições econômicas das partes e a finalidade da reparação, entendeu por bem fixar o montante de $\mathrm{R} \$ 300.000,00$ (trezentos mil reais) a título de danos morais e materiais.

5. Desse modo, considerando que a quantia fixada pelo Tribunal a quo a título de indenização por dano moral e material não escapa à razoabilidade, nem se distancia do bom senso e dos critérios recomendados pela doutrina e pela jurisprudência, forçoso concluir que a pretensão esbarra na vedação contida na Súmula 7 do STJ, por demandar a análise do conjunto fático-probatório dos autos.

6. Agravo regimental não provido. (STJ, AgRg no REsp 1160643/RN, rel. ministro Benedito Gonçalves, Primeira Turma, julgado em 23-112010, DJe 26-11-2010)

Além disso, há ainda dois diplomas legais que preveem indenizações a serem pagas pelo Estado em situações que podem se enquadrar nas práticas de tortura conduzidas nos bens públicos afetados às Forças Armadas - especialmente se delas decorreu o desaparecimento da vítima.

A Lei no 9.140/1995 prevê indenização para as "pessoas desaparecidas em razão de participação, ou acusação de participação, em atividades políticas, no período de 2 de setembro de 1961 a 15 de agosto de 1979" (art. 1º). A indenização consiste no pagamento de valor único, calculado pela multiplicação do valor de R\$ 3 mil para cada ano de expectativa de sobrevida do desaparecido, conforme idade à época do desaparecimento e critérios constantes no Anexo II da Lei (art. 11). Ainda de acordo com a Lei, o valor mínimo da indenização será de 100 mil reais, independentemente da expectativa de sobrevida (art. 11, §1으). 
Já a Lei no 10.559/2002 assegurou ao anistiado político, entre outros, o direito de "reparação econômica, de caráter indenizatório, em prestação única ou em prestação mensal, permanente e continuada" (art. 1o, II). Com isso, visa-se reparar as perdas econômicas sofridas pelo anistiado (considerado aquele enquadrado em uma das várias hipóteses do art. $2^{\underline{o}}$ da Lei $)^{25}$ como consequência de seu envolvimento em atividades políticas exercidas durante o período de 18 de setembro de 1946 até 5 de outubro de 1988. Nesse caso, assegura-se o pagamento de uma reparação econômica única ou periódica, que "correrá à conta do Tesouro Nacional" (art. 3ํ, caput).

25 "Art. 2o São declarados anistiados políticos aqueles que, no período de 18 de setembro de 1946 até 5 de outubro de 1988, por motivação exclusivamente política, foram: I - atingidos por atos institucionais ou complementares, ou de exceção na plena abrangência do termo; II - punidos com transferência para localidade diversa daquela onde exerciam suas atividades profissionais, impondo-se mudanças de local de residência; III - punidos com perda de comissões já incorporadas ao contrato de trabalho ou inerentes às suas carreiras administrativas; IV - compelidos ao afastamento da atividade profissional remunerada, para acompanhar o cônjuge; V - impedidos de exercer, na vida civil, atividade profissional específica em decorrência das Portarias Reservadas do Ministério da Aeronáutica no S-50GM5, de 19 de junho de 1964, e no S-285-GM5; VI - punidos, demitidos ou compelidos ao afastamento das atividades remuneradas que exerciam, bem como impedidos de exercer atividades profissionais em virtude de pressões ostensivas ou expedientes oficiais sigilosos, sendo trabalhadores do setor privado ou dirigentes e representantes sindicais, nos termos do §2o do art. $8^{\circ}$ do Ato das Disposições Constitucionais Transitórias; VII - punidos com fundamento em atos de exceção, institucionais ou complementares, ou sofreram punição disciplinar, sendo estudantes; VIII - abrangidos pelo Decreto Legislativo no 18 , de 15 de dezembro de 1961, e pelo Decreto-Lei no 864, de 12 de setembro de 1969; IX - demitidos, sendo servidores públicos civis e empregados em todos os níveis de governo ou em suas fundações públicas, empresas públicas ou empresas mistas ou sob controle estatal, exceto nos Comandos militares no que se refere ao disposto no §5o do art. 8o do Ato das Disposições Constitucionais Transitórias; X - punidos com a cassação da aposentadoria ou disponibilidade; XI desligados, licenciados, expulsos ou de qualquer forma compelidos ao afastamento de suas atividades remuneradas, ainda que com fundamento na legislação comum, ou decorrentes de expedientes oficiais sigilosos; XII - punidos com a transferência para a reserva remunerada, reformados, ou, já na condição de inativos, com perda de proventos, por atos de exceção, institucionais ou complementares, na plena abrangência do termo; XIII - compelidos a exercer gratuitamente mandato eletivo de vereador, por força de atos institucionais; XIV punidos com a cassação de seus mandatos eletivos nos Poderes Legislativo ou Executivo, em todos os níveis de governo; XV - na condição de servidores públicos civis ou empregados em todos os níveis de governo ou de suas fundações, empresas públicas ou de economia mista ou sob controle estatal, punidos ou demitidos por interrupção de atividades profissionais, em decorrência de decisão de trabalhadores; XVI - sendo servidores públicos, punidos com demissão ou afastamento, e que não requereram retorno ou reversão à atividade, no prazo que transcorreu de 28 de agosto de 1979 a 26 de dezembro do mesmo ano, ou tiveram seu pedido indeferido, arquivado ou não conhecido e tampouco foram considerados aposentados, transferidos para a reserva ou reformados; XVII - impedidos de tomar posse ou de entrar em exercício de cargo público, nos Poderes Judiciário, Legislativo ou Executivo, em todos os níveis, tendo sido válido o concurso. $\$ 1^{\circ}$ No caso previsto no inciso XIII, o período de mandato exercido gratuitamente conta-se apenas para efeito de aposentadoria no serviço público e de previdência social. §2을 Fica assegurado o direito de requerer a correspondente declaração aos sucessores ou dependentes daquele que seria beneficiário da condição de anistiado político." 
Em comum, esses casos comprovam a possibilidade de ocorrência de danos efetivos ao erário, uma vez que o Estado pode ser responsabilizado por atos de tortura praticados em bens públicos que deveriam ser usados conforme sua afetação, isto é, para a execução das atividades legalmente atribuídas às Forças Armadas. Em outras palavras, o desvio do uso dos bens públicos afetados às Forças Armadas para práticas de tortura pode ensejar o direito de reparação (material e moral) às vítimas por tais ilícitos, causando prejuízos ao erário.

Em resumo, tem-se que (i) as evidências colhidas pela Comissão Nacional da Verdade apontam que houve desvio no uso afetado dos bens públicos suporte às atividades das Forças Armadas - , o que, por si só, já se constitui num ilícito possível de causar dano ao patrimônio público; (ii) o "novo uso" atribuído aos bens públicos afetados às Forças Armadas (práticas de tortura) pode ensejar a responsabilização do Estado e, portanto, causar danos ao erário; sendo então que (iii) o desvio de uso dos bens públicos afetados às Forças Armadas para práticas de tortura tem potencial de causar danos ao erário.

Tendo em vista as evidências já colhidas, há risco potencial de que o Estado seja acionado para se responsabilizar pelos danos causados pelo desvio do uso de bens públicos para as práticas de tortura.

Por fim, pela terceira perspectiva, é possível ainda considerar que o uso desconforme dos bens públicos para a prática de tortura tenha causado danos morais ao Estado. Conforme visto no item 3.3, há jurisprudência relevante no sentido de que o Estado pode sofrer, paralelamente aos danos materiais, danos morais por uma determinada conduta ilícita, ensejando o dever de compensação pelo seu causador. Assim, seria possível entender que a prática de atos de tortura por agentes estatais causou dano moral ao Estado brasileiro - práticas que inclusive têm sido questionadas em cortes internacionais de proteção aos direitos humanos. Causa-se, com isso, um dano moral ao Estado e, em especial, à sociedade, tendo em vista o grau de reprovabilidade das práticas de tortura. Destarte, a se defender tal tese, o desvio do uso de bens públicos afetados às Forças Armadas para práticas de tortura enseja ainda um dano moral ao Estado.

Em conclusão, há evidências de um ilícito (desvio no uso dos bens públicos afetados às Forças Armadas) capaz de causar diversos danos aos interesses públicos e ao erário (possibilidade de prejuízo ao fim público afetado, ao patrimônio público pelo uso desconforme e gratuito, ao erário por eventual responsabilização do Estado pelo novo uso, ao Estado pelos danos morais que podem ser causados pelo novo uso). 
Tendo em vista os potenciais danos que o desvio no uso dos bens públicos afetados às Forças Armadas para práticas de tortura pode ensejar ao erário, o Estado tem o dever de apurar a responsabilidade por esses desvios e, comprovando-se o dano efetivo ao erário, cobrar regressivamente o agente responsável pelos danos causados.

É mister que o Estado investigue se houve desvio por ter sido o bem (i) utilizado fora de sua afetação; ou (ii) utilizado por terceiros sem título habilitante ou, ainda, (iii) utilizado em desacordo com as normas das Forças Armadas.

Verificado, nesses casos, o dano efetivo ao erário - por exemplo, determinada indenização a ser paga pelo Estado em razão de prática de tortura num determinado bem público afetado às Forças Armadas - , o Estado poderá (de fato, deverá) cobrar o ressarcimento desse dano por seu responsável, sem prejuízo de outras eventuais responsabilidades que sejam a ele aplicadas em razão do uso desconforme dos bens públicos. A possibilidade de abertura de procedimento administrativo investigativo, as questões a serem esclarecidas e eventuais regras procedimentais a serem observadas são objeto do tópico seguinte.

\section{Dever de apuração dos indícios de desvio de uso dos bens públicos}

Tendo em vista a existência de indícios de que houve desvio no uso de bens públicos afetados às Forças Armadas - que passaram a ser indevida e ilicitamente utilizados para práticas de torturas - - , tem-se então o dever do Estado em apurar tais indícios. O presente tópico tem por objetivo analisar algumas questões procedimentais relacionadas ao dever (e à forma) dessa apuração, com o escopo de delimitar os meios possíveis para sua condução.

\subsection{Viabilidade jurídica da apuração dos indícios}

Superada a análise acerca do regime jurídico aplicável aos bens destinados às Forças Armadas e delimitadas as consequências em caso de eventual uso em desconformidade com a afetação pública a eles conferida, passamos agora a identificar se, diante dos indícios de desvio no uso dos bens públicos afetados às Forças Armadas apurados pela Comissão Nacional da Verdade, é 
juridicamente viável a abertura de procedimento ou processo administrativo, comum ou militar, para investigar se, de fato, houve uso desconforme e identificar responsabilidades por tal desvio.

O estudo sobre a viabilidade jurídica da apuração dos indícios de desvio de uso de bens públicos, com eventual e posterior responsabilização dos agentes, deverá considerar (i) aspectos relacionados ao veículo correto de apuração do desvio de uso de bens públicos, no sentido de verificar a possibilidade de apuração do desvio de uso por meio de processos administrativos ou procedimentos militares, tal qual a sindicância, bem como (i) as questões relacionadas à prescrição e à indulgência da Lei da Anistia, considerando que os atos a serem investigados foram praticados entre 1944 e 1988.

\subsubsection{A lei no tempo: considerações gerais sobre irretroatividade e prescrição}

Para analisar a viabilidade jurídica da instauração de procedimentos para averiguação do desvio de uso de bens entre as décadas de 1940 e 1980, não é possível ignorar o problema da eficácia da lei no tempo e da prescrição do jus puniendi no que diz respeito à eventual responsabilização do agente militar pela conduta faltosa.

No Brasil, sabemos, o constituinte optou por um "sistema em que não se proíbe diretamente a existência de leis retroativas, mas apenas excluemse da retroatividade da lei nova algumas espécies de atos" ${ }^{26}$ Assim, nem a Constituição, nem a lei ordinária consignam a proibição de leis retroativas, mas "apenas excluem da incidência da lei nova o ato jurídico perfeito, o direito adquirido e a coisa julgada". ${ }^{27}$

Embora nem sempre tenha sido assim, não nos compete, no presente estudo, fazer um apanhado do tema desde a Constituição do Império. Basta delinear o tratamento constitucional do tema no período compreendido entre os trabalhos desenvolvidos pela Comissão Nacional da Verdade, qual seja, 18 de setembro de 1946 a 5 de outubro de 1988.

Nesse sentido, vale dizer que a Constituição de 1946 determinava, no art. 141, §3ำ que "a lei não prejudicará o direito adquirido, o ato jurídico perfeito e a coisa julgada".

26 RODRIGUES, Silvio. Direito civil: parte geral. São Paulo: Saraiva, 2003. v. 1, p. 26.

27 Ibid., v. 1, p. 26. 
Já em 1957, a Lei no 3.238 alterou a Lei de Introdução ao Código Civil (Decreto-lei no 4.657, de 4 de setembro de 1942, hoje chamado "Lei de Introdução às normas do Direito Brasileiro"), que passou a ter a seguinte redação:

Art. 6o A Lei em vigor terá efeito imediato e geral, respeitados o ato jurídico perfeito, o direito adquirido e a coisa julgada.

$\S 1$ o Reputa-se ato jurídico perfeito o já consumado segundo a lei vigente ao tempo em que se efetuou.

\$2을 Consideram-se adquiridos assim os direitos que o seu titular, ou alguém por ele, possa exercer, como aqueles cujo começo do exercício tenha termo pré-fixo, ou condição preestabelecida inalterável, a arbítrio de outrem.

§3ํㅡㄹ Chama-se coisa julgada ou caso julgado a decisão judicial de que já não caiba recurso.

Por sua vez, a Constituição de 1967 (alterada pela Emenda Constitucional no 1, de 17 de outubro de 1969) consignava preceito idêntico ao da Carta de 1946. A regra foi mantida nos mesmos termos pela Constituição vigente, conforme prescrito em seu art. 5o, XXXVI.

Assim, embora os indícios apurados pela Comissão Nacional da Verdade apontem para a existência de fatos nascidos sob o regime constitucional diverso do atualmente vigente, temos que os procedimentos que venham a ser instaurados para apurar o desvio de uso de bens públicos entre 1946 até 1988 estarão sujeitos à mesma regra quanto à irretroatividade das leis, qual seja, "a lei retroage, apenas não se permite que ela recaia sobre o ato jurídico perfeito, sobre o direito adquirido e sobre a coisa julgada". ${ }^{28}$

Isso significa que, diante dos indícios de desvio de uso dos bens públicos, as autoridades administrativas (militares ou não) deverão observar as regras atuais do ordenamento para determinar a instauração dos procedimentos adequados para a averiguação dos fatos (processos administrativos, processos disciplinares militares, sindicâncias etc.). Contudo, a determinação acerca da regularidade ou irregularidade do uso dos bens públicos deverá levar em conta as normas de direito material aplicáveis à época.

28 Ibid., v. 1, p. 29. 
A título de exemplo, podemos imaginar que parte do material colhido pela Comissão Nacional da Verdade resulte em averiguação, no âmbito das Forças Armadas, que permitiria qualificar determinado ato como um crime contra o patrimônio, tal como tipificado atualmente no Código Penal Militar (Decreto-Lei no 1.001). ${ }^{29}$ Porém, caso o desvio do uso tenha ocorrido antes da promulgação desse Código (21 de outubro de 1961), será preciso recorrer à norma aplicável à época para possibilitar a correta tipificação e a consequente (e eventual) responsabilização pelo ilícito. No exemplo aventado, temos que o "crime de dano" contra o patrimônio também era tratado no art. 211 do Código Penal anterior, o Decreto-Lei nº 6.227, de 24 de janeiro de 1944, porém em outros termos. ${ }^{30} \mathrm{Ou}$ seja, talvez um ato que a partir do início da vigência do Código Penal de 1969 pudesse ter tipificado como um "crime contra o patrimônio" no âmbito do direito penal militar, antes dessa data não fosse assim considerado. $\mathrm{O}$ contrário, por óbvio, também pode se dar.

De mais a mais, além do eventual enquadramento do ato de desvio dos bens como transgressão, contravenção ou crime, a depender da norma militar aplicável, para que a responsabilização do servidor militar se dê, há que se verificar também se o jus puniendi não está prescrito. É dizer, a investigação dos fatos pode concluir que de fato houve um desvio de bens públicos (caracterizável como crime, transgressão ou contravenção), porém o servidor poderá vir a não ser responsabilizado por crime militar (ou mesmo comum), seja porque o prazo está prescrito, seja porque se encontram abarcados pela indulgência da Lei da Anistia (ver item 4.1.1.2).

Frisa-se que as regras de prescrição incidentes na esfera militar e na esfera administrativa ou civil são diversas, portanto, ainda que o direito de punir no âmbito do direito penal ou militar esteja extinto, é possível que remanesça a possibilidade de responsabilizar um agente no âmbito administrativo ou civil (nesse sentido, destaca-se a imprescritibilidade das ações de ressarcimento de dano ao erário, objeto do item 4.1.1.1. deste estudo).

Assim, no âmbito das Forças Armadas, temos que o dever de apuração dos indícios de desvio de uso poderá se dar por meio da instauração de sindicância, nos termos expostos no item 4.2.2. Já no âmbito da administração federal, conforme veremos no item 4.2.1, é a lei de processo administrativo que deverá ser observada.

29 Cf. arts. 259, parágrafo único, 262, 263, 264, 265 e 266.

30 Cf. arts. 211, 212, 213, 214 e 215. 
Definido o veículo correto para a apuração da irregularidade a depender de quanto se apurou pela Comissão Nacional da Verdade, entendemos, conforme mencionado na Consulta, ser possível que o desvio de bens para a prática de tortura tenha se dado: (i) como política de Estado, ordenada expressamente pelos escalões superiores das Forças Armadas no afã de combater o "comunismo", ou as forças contrárias à suposta revolução de 1964; (ii) em investigações corriqueiras, relacionadas a crimes comuns, sem nenhuma relação com as questões de preservação do golpe de 1964 ou do combate ao comunismo internacional; (iii) por grupos radicais, dentro das Forças Armadas, contra ordem superior, como afronta aos dirigentes do Estado e, enfim, (iv) com finalidades particulares, sem nenhuma relação política ou criminal.

Cada uma dessas situações, se devidamente esclarecidas, pode ter um enfoque diverso sob o prisma do desvio de bens, da responsabilidade civil regressiva e, até mesmo, da aplicação da Lei da Anistia. Isso porque, como veremos amiúde a seguir, caso o desvio de uso tenha se dado com os militares agindo em função de comandos estatais, será possível extinguir a punibilidade penal dos agentes em razão do eventual enquadramento de tais atos na Lei no 6.683/1979, a chamada Lei da Anistia.

\subsubsection{Imprescritibilidade de ação contra potenciais danos ao erário}

Como visto no item 3.3, os prejuízos eventualmente ensejados ao patrimônio público pelo desvio do uso afetado de bens podem gerar, ao menos, dois âmbitos de responsabilização: (i) a do Estado perante os cidadãos e a coletividade afetada, em razão dos prejuízos causados à função pública afetada ao bem; (ii) a do agente estatal responsável pelo desvio do uso afetado perante o Estado, em razão do dano ao patrimônio público decorrente do uso desconforme do bem.

Quanto ao primeiro âmbito de responsabilidade, tanto os cidadãos em geral, quanto a coletividade diretamente afetada pelo desvio do uso de determinado bem público podem, diretamente ou por meio de seus representantes, pleitear o ressarcimento de danos ao erário. Quanto ao segundo, não só é possível, como constitui um poder-dever das autoridades competentes a responsabilização dos agentes sob seu comando por eventuais danos por eles causados em decorrência do uso indevido de bens públicos (nesse sentido, ver item 4.2.2.). Resta saber se a pretensão de ressarcimento pelo prejuízo causado ao erário é imprescritível. 
A dúvida poderia ser respondida levando-se em conta a Constituição Federal vigente, pois, embora haja controvérsias, prevalece hoje na jurisprudência o entendimento de que o seu art. 37, §5ำ prevê a imprescritibilidade de cobrança de ressarcimento pelos potenciais danos ao erário. ${ }^{31}$

De fato, a jurisprudência se inclina no sentido de entender imprescritível ação de ressarcimento do erário, inclusive por improbidade administrativa. Tal ressalva é importante para o presente estudo por dois motivos. O primeiro é que a Lei de Improbidade Administrativa (Lei no 8.429, de 2 de junho de 1992), em uma interpretação extensiva, pode ser aplicada aos servidores militares caso seus regimentos disciplinares e normas específicas não tratem dos mesmos temas abarcados pela mencionada Lei. O segundo é que a Lei de Improbidade Administrativa determina, no seu art. 23, que

as ações destinadas a levar a efeitos as sanções previstas nesta lei podem ser propostas: I - até cinco anos após o término do exercício de mandato, de cargo em comissão ou de função de confiança; II - dentro do prazo prescricional previsto em lei específica para faltas disciplinares puníveis com demissão a bem do serviço público, nos casos de exercício de cargo efetivo ou emprego.

O que poderia levar o mau intérprete a entender que o prazo prescricional apontado aplicar-se-ia às ações de ressarcimento, o que não é verdade, conforme podemos depreender do apanhado da jurisprudência mais recente. Vejamos, entre outras:

EMENTA: ADMINISTRATIVO E PROCESSUAL CIVIL. AÇÃO CIVIL. REPARAÇÃO DE DANOS AO ERÁRIO. APURAÇÃO DO TRIBUNAL DE CONTAS. EX-VEREADORES. VALORES RECEBIDOS A MAIOR. IMPRESCRITIBILIDADE. PRECEDENTES DO STF E STJ.

1. Diante da jurisprudência consolidada no STF e STJ, a pretensão de ressarcimento ao erário, independentemente de se tratar ou não de ato de improbidade administrativo, é imprescritível.

31 Art. 37 (...) §5 “a lei estabelecerá os prazos de prescrição para ilícitos praticados por qualquer agente, servidor ou não, que causem prejuízos ao erário, ressalvadas as respectivas ações de ressarcimento". 
2. Recurso especial provido (STJ, REsp 1350656/MG RECURSO ESPECIAL 2012/0224343-9, relator(a) ministra Eliana Calmon (1114), Órgão Julgador T2 - Segunda Turma, Data do Julgamento 5-9-2013, Data da Publicação/Fonte DJe 17-9-2013)

EMENTA: PROCESSUAL CIVIL E ADMINISTRATIVO. AÇÃO CIVIL PÚBLICA. IMPROBIDADE ADMINISTRATIVA. APLICAÇÃO DA LEI 8.429/1992 AOS AGENTES POLÍTICOS. COMPATIBILIDADE COM O DECRETO-LEI 201/1967. RESSARCIMENTO DE DANO AO ERÁRIO PÚBLICO. IMPRESCRITIBILIDADE. DEMAIS SANÇÕES. ART. 23 DA LIA. TERMOS INICIAIS DISTINTOS CONFORME O VÍNCULO DO AGENTE COM A ADMINISTRAÇÃO. (....)

2. A ação de ressarcimento dos prejuízos causados ao erário é imprescritível, mesmo se cumulada com a ação de improbidade administrativa (art. 37, §5०, da CF).

3. Não fere as garantias constitucionais a previsão de termos iniciais distintos, para fins de contagem da prescrição para as demais sanções, nos moldes do art. 23, I e II, da LIA, conforme o vínculo jurídico do agente público com a Administração.

4. Agravo regimental não provido. (STJ, AgRg no AREsp 79268/MS, AGRAVO REGIMENTAL NO AGRAVO EM RECURSO ESPECIAL 2011/0190020-3, relator(a) ministra Eliana Calmon (1114), Órgão Julgador T2 - Segunda Turma, Data do Julgamento 19-11-2013, Data da Publicação/Fonte DJe 29-11-2013)

Note-se que, mesmo antes da edição da Lei no 8.429 , a prática de improbidade administrativa, sob o prisma do direito material, já impunha ao infrator a obrigação de ressarcimento aos cofres públicos. De mais a mais, no período de investigação compreendido pela Comissão Nacional da Verdade também estavam vigentes normas que condenavam, direta ou indiretamente, o uso indevido de bens públicos.

Mais uma vez verifica-se a necessidade de se apurar, individualmente, todos os indícios de uso indevido dos bens das Forças Armadas. Isso porque somente com a delimitação temporal precisa da ocorrência dos fatos, combinada com o mapeamento das circunstâncias de sua realização, será possível identificar as normas aplicáveis e as relações jurídicas que dali nasceram para, por fim, determinar eventuais responsabilizações de agentes militares por danos causados ao Erário. 


\subsubsection{A responsabilização do agente e a anistia concedida pela Lei $n^{\circ} 6.683 / 79$}

A Lei no 6.683, de 28 de agosto de 1979, concedeu anistia a todos quantos, no período compreendido entre 2 de setembro de 1961 e 15 de agosto de 1979, cometeram crimes políticos ou conexos com estes, crimes eleitorais, aos que tiveram seus direitos políticos suspensos e aos servidores da administração direta e indireta, de fundações vinculadas ao poder público, aos servidores dos Poderes Legislativo e Judiciário, aos militares e aos dirigentes e representantes sindicais, punidos com fundamento em atos institucionais e complementares.

O Supremo Tribunal Federal, no julgamento da ADPF no $153-D F$, que declarou a recepção da Lei da Anistia pela ordem constitucional vigente, esclareceu que o que se procurou "(...) [foi] estender a anistia criminal de natureza política aos agentes do Estado encarregados da repressão".

Pois bem. Admitindo a conformidade da Lei da Anistia com o ordenamento constitucional vigente, entende-se ser vedada a responsabilização penal por crimes de qualquer natureza relacionados com crimes políticos ou praticados por motivação política cometidos no período determinado pelo diploma.

De mais a mais, conforme dispõe o Estatuto dos Militares (Lei no ${ }^{-6.880 / ~}$ 1980) vigente, “[a] violação das obrigações ou dos deveres militares constituirá crime, contravenção ou transgressão disciplinar, conforme dispuser a legislação ou regulamentação específicas" (art. 42, caput) e "no concurso de crime militar e de contravenção ou transgressão disciplinar, quando forem da mesma natureza, será aplicada somente a pena relativa ao crime" (art. 42, $\S 2^{\circ}$ ). É dizer: caso durante a apuração do desvio de uso de bens este venha a ser caracterizado como uma transgressão, contravenção ou crime militar que tenha natureza política, não haverá que se falar em responsabilização do agente.

Por isso dissemos que é preciso investigar em quais circunstâncias se deu o desvio de uso de bens. Caso o desvio tenha se dado como política de Estado, ordenada expressamente pelos escalões superiores das Forças Armadas no afã de combater o "comunismo", ou as forças contrárias à suposta revolução de 1964, estaríamos diante da possibilidade de enquadrar os efeitos penais do desvio do uso na Lei da Anistia. Contudo, importa relevar que, mesmo nesta hipótese, o uso de bens públicos para a prática de tortura 
poderá apresentar consequências que extrapolam a esfera penal, e a Lei da Anistia poderá não fulminar todos os efeitos que determinado ato causou. Nas palavras de Edgard Magalhães de NORONHA:

[A anistia] não se limita a excluir a pena, extingue o próprio crime e com ele todos os seus efeitos penais. Só lhe sobrevivem as obrigações de ordem civil. Caberá sempre ao responsável pelo dano o dever de indenizá-lo. (...). Não se alcança a reparação civil a anistia, já que ela é tão somente renuncia ao jus puniendi. ${ }^{32}$

No que diz respeito especificamente à atuação dos servidores militares, Álvaro Lazzarini ressalta a possibilidade de sua reparação em diversas esferas:

(...) a responsabilidade do militar quando inobservar os seus deveres será de ordem civil, criminal, administrativa e política. Responsabilidade civil, de natureza pecuniária, com a reparação de dano que causar; responsabilidade criminal, em havendo crime militar e, eventualmente, comum; responsabilidade administrativa, que será disciplinar em razão do Poder Disciplinar; aplicando-se ao militar as sanções previstas no Regulamento Disciplinar, a hierárquica, como nas hipóteses em que o superior hierárquico competente, não como sanção disciplinar, movimenta o subordinado faltoso para lugar diverso daquele em que cometeu a falta. Por fim, responsabilidade política, dado que o servidor militar sujeita-se ao princípio da probidade administrativa previsto no art. 37, §4º da vigente Constituição de 1988, regulada pela Lei n. 8.429, de 2 de junho de $1992 .{ }^{33}$

Nesse sentido, tendo em vista os tipos de responsabilização que o uso indevido de bens pode gerar, é primordial que a investigação administrativa instaurada por meio de sindicância ou de processo administrativo adequado para apuração dos fatos busque indicar o fundamento do ato que se traduziu

32 NORONHA, Edgard Magalhães de. Direito penal. 8. ed. São Paulo: Saraiva, 1983. v. 1, p. 379-380.

33 LAZZARINI, Álvaro. Servidores militares. In: DALLARI, Adilson Abreu; NASCIMENTO, Carlos Valder do; MARTINS, Ives Gandra (Coord.). Tratado de direito administrativo. São Paulo: Saraiva, 2013. p. 265. 
em desvio de uso de bens caso a caso. Como não se tem conhecimento de norma que tenha autorizado a tortura mediante o uso de bens das Forças Armadas, é preciso averiguar (i) se os militares agiram sob comando de superiores hierárquicos, no cumprimento de deveres subjacentes a uma política de Estado; ou (ii) se os militares fizeram uso indevido de bens das Forças Armadas para atingimento de objetivos particulares ou em patente abuso de poder.

Caso os militares tenham agido sob mando de superiores hierárquicos, a apuração dos fatos deverá indicar se o emprego de bens das Forças Armadas para a prática de tortura, além de irregular, foi criminoso. Isso porque os militares que tenham cometido crimes contra o patrimônio tipificados durante o mencionado período, por força de comandos superiores, podem se beneficiar da indulgência estatal, se se entender que este crime militar é conexo a um crime político, dado o contexto histórico de sua ocorrência. Entretanto, caso os desvios no uso dos bens tenham se dado em período diverso daquele compreendido pela Lei no ${ }^{-6.683 / 1979, ~ a ~ a n i s t i a ~ a o ~ c r i m e ~ n a ̃ o ~ s e ~ v e r i f i c a r a ́ . ~}$

De mais a mais, os efeitos da anistia restringem-se à esfera penal, mas os crimes e as transgressões verificados no uso indevido de uso de bens públicos (ainda que por força de comando superior) podem resultar em efeitos não penais, como o dever de indenização pelos danos civis, patrimoniais.

Caso, entretanto, os servidores militares tenham feito uso indevido de bens das Forças Armadas para a prática de atos de tortura sem qualquer tipo de comando estatal, não há que se falar em crime político: nesse caso, estar-se-á diante de uma transgressão de conduta ou de um crime militar comum (a depender da apuração dos fatos), não abarcado pela indulgência concedida por meio da Lei da Anistia.

\subsection{Procedimentalização da apuração}

Conforme veremos, para a averiguação do desvio de uso de bens temos que é possível tanto a instauração de processo administrativo comum, nos termos da Lei no 9.784, de 29 de janeiro de 1999, quanto a instauração de sindicâncias no âmbito das Forças Armadas.

A finalidade precípua da instauração desses processos ou procedimentos será investigar (i) se houve o uso indevido de bens públicos, bem como se o referido desvio se caracterizou por ter sido o bem (i.a) utilizado fora de 
sua afetação, (i.b) utilizado por terceiros sem título habilitante ou, ainda, (i.c) utilizado em desacordo com as normas das Forças Armadas; (ii) se esse uso gerou prejuízo efetivo ao erário ou pode ainda gerar (por meio de ações de indenizações movidas pelas vítimas); (iii) se esse uso foi direto por integrantes das forças ou consentido a terceiros; (iv) se esse uso se deu por ordem superior ou clandestinamente; (v) se há possibilidade de se responsabilizar regressivamente, por dano ao erário, algum agente público (seja por ação, seja por omissão); (vi) se todos os atos encontram-se amparados pela Lei da Anistia, uma vez que resultado de uma política de Estado voltada ao combate dos grupos ligados ao comunismo internacional ou simplesmente grupos insurgentes contra o Golpe de 64, talvez não haja incompatibilidade entre o administrativo disciplinar e o processo para apuração de responsabilidade civil regressiva do servidor.

Em que pese as variáveis apontadas, certo é que as consequências geradas pelo uso irregular dos bens só poderão ser precisamente mapeadas por meio de investigações destinadas a descobrir as circunstâncias em que se deu cada uso irregular, sem que isso gere, necessariamente, responsabilização dos militares na ativa ou na inatividade - seja por conta das regras de prescrição, seja por conta da extinção da punibilidade penal trazida pela Lei da Anistia.

Enfim, vale dizer que não se verifica a existência de bis in idem no fato de o agente, pela mesma conduta, ser apenado civil (responsabilidade civil), criminal e disciplinarmente. Sobre o tema, Lazzarini anota que

(...) há autonomia da instância administrativa disciplinar, do que decorre inexistir bis in idem no fato de o agente, pela mesma conduta, ser apenado civil (responsabilidade civil), criminal e disciplinarmente. Bis in idem só haverá se o servidor militar vier a ser punido disciplinarmente duas ou mais vezes pela mesma conduta, pela mesma ou diversa autoridade a que se sujeite hierarquicamente. $\mathrm{O}$ bis in idem, como é sabido, é a repetição (bis) da punição sobre a mesma conduta faltosa (in idem). ${ }^{34}$

34 Lazzarini, Servidores militares, op. cit., p. 264. 


\subsubsection{No âmbito da administração pública federal}

Considerando os indícios apurados pela Comissão Nacional da Verdade, é possível a instauração de um processo administrativo para a averiguação do desvio de uso de bens públicos, nos termos da Lei no 9.784, de 29 de janeiro de 1999. Isso porque, entre as finalidades do processo administrativo, está a averiguação do correto desempenho das funções administrativas. Não por menos o art. 1ำ da mencionada Lei dispõe que "Esta Lei estabelece normas básicas sobre o processo administrativo no âmbito da Administração Federal direta e indireta, visa, em especial, à proteção dos direitos dos administrados e ao melhor cumprimento dos fins da Administração".

Assim, é dever da administração investigar se houve desvio do uso de bens públicos e, se for o caso, proceder à responsabilização do agente pelos prejuízos que tal conduta possa ter gerado.

Entre as diversas finalidades do processo administrativo que hoje se pode assinalar, ${ }^{35}$ temos que a averiguação dos dados colhidos pela Comissão Nacional da Verdade se prestaria, ao menos, a demonstrar (i) se houve de fato um desvio no uso de bens públicos; (ii) se a atuação dos agentes estava eivada de ilegitimidade; (iii) se desse desvio decorreu danos ao erário (iii.a) que ensejem a responsabilização civil regressiva do servidor.

Nesse sentido, em linhas gerais, o processo administrativo se prestaria a averiguar se houve legitimidade no exercício do poder do agente estatal responsável pelo desvio do uso de bens, bem como se o desempenho da função estatal foi adequada. Em outras palavras, com a instauração do processo administrativo, seria possível saber se a ação do agente estatal foi correta ou aceitável e, ainda, se o poder foi exercido de acordo com as finalidades para as quais foi atribuído.

Note-se que o processo administrativo pode iniciar-se de ofício ou a pedido de interessado (art. 5o) e são legitimados como interessados no processo administrativo (i) pessoas físicas ou jurídicas que o iniciem como titulares de direitos ou interesses individuais ou no exercício do direito de representação;

35 "Se num primeiro momento o processo administrativo significava meio de observância dos requisitos de legalidade do ato administrativo e garantia de respeito dos direitos dos indivíduos, seus objetivos foram se ampliando à medida que se alteravam as funções do Estado e da Administração, as relações entre Estado e sociedade e as próprias concepções do direito administrativo. Extrapolou-se o perfil do processo administrativo ligado somente à dimensão do ato administrativo em si, para chegar à legitimação do poder." (MEDAUAR, Odete. Direito administrativo moderno. 12. ed. São Paulo: Revista dos Tribunais, 2008. p. 162). 
(ii) aqueles que, sem terem iniciado o processo, têm direitos ou interesses que possam ser afetados pela decisão a ser adotada; (iii) as organizações e associações representativas, no tocante a direitos e interesses coletivos; e (iv) as pessoas ou as associações legalmente constituídas quanto a direitos ou interesses difusos (art. 9o).

Por fim, importa notar que a instauração de processo no âmbito da administração pública federal não impede que as Forças Armadas também busquem, por meios dos seus próprios instrumentos, averiguar os mesmos indícios de desvio de uso de bens públicos trazidos pela Comissão Nacional da Verdade, nem impede que dessa investigação decorram consequências específicas de responsabilização dos agentes em função das regras atinentes ao direito militar - ressalvados, como já dito, os casos de prescrição e aqueles efeitos penais abarcados pela Lei da Anistia.

\subsubsection{No âmbito das Forças Armadas}

Se é certo que o Estado, por meio da autoridade competente, tem o dever de apurar as responsabilidades pelo uso desconforme de bens públicos, deve-se trazer à baila as regras específicas das Forças Armadas atinentes à instauração de sindicância. Embora não se ignore o fato de que o uso indevido de bens possa, a rigor, dar ensejo também às ações penais militares (no caso de caracterização do crime contra o patrimônio) e processos administrativos disciplinares, este estudo se aterá à análise da possibilidade de instauração da sindicância pois, no âmbito das Forças Armadas, fundamentalmente é ela que se presta a verificar se há indícios de crime militar ${ }^{36}$ ou comum, transgressão disciplinar ou prejuízo ao erário.

No caso em tela, temos que o desvio de uso de bens poderá se enquadrar em qualquer uma das quatro hipóteses. Portanto, provavelmente a sindicância será o instrumento mais adequado para desenvolver, ao menos, a apuração inicial dos fatos.

No que diz respeito às contravenções e transgressões disciplinares, o art. 47 do Código Penal Militar, aplicável a todos os militares das Forças Armadas, determina que

36 Note-se que tanto o Código Penal Militar vigente (instituído pelo Decreto-Lei no 1.001, de 21 de outubro de 1969), quanto o anterior (promulgado pelo Decreto-Lei no 6.227 , de 24 de janeiro de 1944), tratam de crimes contra o patrimônio. Este, inclusive, tipificava o dano à "coisa sob administração militar" (art. 211). 
[o]s regulamentos disciplinares das Forças Armadas especificarão e classificarão as contravenções ou transgressões disciplinares e estabelecerão as normas relativas à amplitude e aplicação das penas disciplinares, à classificação do comportamento militar e à interposição de recursos contra as penas disciplinares.

Por isso, conforme veremos, cada uma das três Forças busca, em seus regimentos, ${ }^{37}$ especificar o que se entende por transgressão disciplinar e contravenção.

\subsubsection{Exército}

A sindicância, no âmbito do Exército Brasileiro, teve seus procedimentos padronizados pela Portaria no ${ }^{-107}$, de 13 de fevereiro de 2012, que aprovou as "Instruções Gerais para a elaboração de Sindicância no Âmbito do Exército Brasileiro (EB 10 - IG - 09.0001)". Segundo essas Instruções, a sindicância se presta à apuração, quando julgada necessária pela autoridade competente, de fatos de interesse da administração militar ou de situações que envolvam direitos (art. $2^{\circ}$ ).

No que diz respeito à natureza da sindicância, o $\S 1^{\circ}$ do art. $2^{\circ}$ determina que

[n]a hipótese de não ser possível identificar a pessoa diretamente envolvida no fato a ser esclarecido, a sindicância terá caráter meramente investigatório; entretanto, sendo identificada a figura do sindicado desde sua instauração ou ao longo da apuração, o procedimento assumirá caráter processual, devendo ser assegurado àquele o direito ao contraditório e à ampla defesa.

Importa destacar que a regra contida no $\S 20$ do art. $2^{\circ}$ estabelece que, além das hipóteses em que legislação específica o determinar, diante de irregularidades em que não haja a previsão legal de adoção de outros instrumentos

37 Em virtude da inexistência de um banco de dados oficial que contenha as normas atinentes à instauração de sindicância no âmbito das Forças Armadas, o arcabouço jurídico a seguir apresentado foi colhido por meio do uso de ferramentas de pesquisa disponíveis na internet. 
hábeis ao esclarecimento e solução dos fatos, a instauração da sindicância será obrigatória. Ou seja, enxergamos aqui um poder-dever da autoridade do Exército de instaurar a abertura de sindicância quando tomar conhecimento de fato que aponte para a violação de direitos ou que seja de interesse da administração militar.

Ademais, será competente para instaurar a sindicância: (i) o comandante do exército; (ii) o oficial-general no cargo de comandante, chefe, diretor ou secretário de OM; e (iii) o comandante, chefe ou diretor de organização militar (art. $4^{\circ}$ ).

De especial interesse para o presente estudo é a regra estabelecida no art. 8o in verbis: "[q]uando o objeto da apuração for acidente ou dano com viatura, material bélico, material de comunicações ou outro material, deverá ser observado o disposto nas normas específicas de cada órgão de apoio". Note-se que, em termos gerais, a norma em apreço busca tutelar a integridade dos bens do Exército, mas respeitando os regimentos disciplinares de cada repartição, determinando que a apuração dos fatos se dê observando as normas específicas aplicadas ao caso. Entende-se que assim deve ocorrer com as sindicâncias a serem instauradas para apuração de desvio de uso de bens públicos para práticas de tortura. É dizer, a depender de cada caso, há que se observar a norma à época aplicável ao agente para que se possa determinar o cabimento de responsabilização, se for o caso. ${ }^{38}$

Nesse sentido, vale notar que a sindicância poderá fundamentar a aplicação de sanção disciplinar, desde que esta esteja previamente definida no regulamento aplicável ao transgressor da norma. Assim, se entendida a sindicância como um procedimento investigativo e punitivo, ela poderá ser praticamente equivalente a um processo administrativo disciplinar.

Por fim, nos termos no art. 6º da Portaria no 107, o sindicante deverá encerrar a apuração com um relatório completo e objetivo, contendo o seu parecer conclusivo sobre a elucidação do fato. Este relatório deverá mencionar se há ou não indícios de crime militar ou comum, transgressão disciplinar ou prejuízo ao erário ou qualquer outra situação ampliativa ou restritiva de direito, recomendando, se for o caso, a adoção de outras providências.

38 Note-se que regra idêntica àquela presente no art. $8^{\circ}$ da Portaria $n^{-} 793$ já constava da Portaria n 202 , de 26 de abril de 2000, porém não obtivemos sucesso em reunir todas as Portarias do Exército que tratam de sindicância desde 1946 para saber se havia (e qual era) tratamento específico ao uso indevido de bens públicos. 


\subsubsection{Marinha}

Já no âmbito da Marinha, o Regulamento Disciplinar vigente, aprovado pelo Decreto no 88.545, de 26 de julho de 1983, com posteriores alterações, e aplicável aos militares da Marinha da ativa, da reserva remunerada e aos reformados, determina que, "quando houver necessidade de maiores esclarecimentos sobre a contravenção, a autoridade mandará proceder a sindicância ou, se houver indício de crime, a inquérito, de acordo com as normas e prazos legais" (art. 26, §2).

Dentre o extenso rol de contravenções disciplinares registradas no art. 7으, aquelas que mais se aproximam das possibilidades de irregularidades que possam se verificar em decorrência do material apresentado pela Comissão Nacional da Verdade, são: (i) tratar com excessivo rigor preso sob sua guarda; ${ }^{39}$ (ii) extraviar ou concorrer para que se extraviem ou se estraguem quaisquer objetos da Fazenda Nacional ou documentos oficiais, estejam ou não sob sua responsabilidade direta (art. 7으, item 48), ${ }^{40}$ (iii) fazer uso indevido de viaturas, embarcações ou aeronaves pertencentes à Marinha, desde que o ato não constitua crime (art. 70, item 81).

\subsubsection{Aeronáutica}

Enfim, no âmbito do Comando da Aeronáutica, é a Portaria no 545/GC3, de 17 de maio de 2006 que aprova a reedição da Instrução ICA 111-2, que dispõe sobre Sindicância no âmbito do Comando da Aeronáutica.

Aqui, a sindicância é definida como um procedimento de caráter meramente investigatório, utilizado para a apuração de fatos ou ocorrências anômalas que não constituam crime, as quais, caso confirmadas, poderão ensejar a abertura do competente processo. Assim, busca-se investigar as transgressões disciplinares, definidas na Instrução do Comando da Aeronáutica em comento praticamente da mesma forma que vem definida no Regulamento do Exército, qual seja:

39 O tratamento com excesso de rigor de presos sob guarda da Marinha já era considerado uma contravenção nos termos do art. 7o, item 21, do Decreto oㅜ 38.010, de 5 de outubro de 1955, que aprovava o regulamento disciplinar para a Marinha.

40 Da mesma forma, o extravio de objetos da Fazenda Nacional também era considerado uma contravenção nos termos do art. 7o, item 45, do mencionado Decreto oㅜ 38.010, de 5 de outubro de 1955. 
transgressão disciplinar é toda ação praticada pelo militar contrária aos preceitos estatuídos no ordenamento jurídico pátrio ofensiva à ética, aos deveres e às obrigações militares, mesmo na sua manifestação elementar e simples, ou, ainda, que afete a honra pessoal, o pundonor militar e o decoro da classe. (art. 14 do Decreto no 4.346, de 26 de agosto de 2002, que aprova o Regulamento Disciplinar do Exército)

Assim, caso a autoridade competente da Aeronáutica de posse do material colhido pela Comissão Nacional da Verdade reconheça que o desvio de bens das Forças Armadas pode se caracterizar como ação contrária aos preceitos estatuídos no ordenamento jurídico pátrio ofensiva à ética, aos deveres e às obrigações militares, deverá ser instaurada sindicância, num prazo máximo de 48 horas, nos termos do art. 3ํ da Instrução aprovada pela Portaria no $545 /$ GC3.

Por fim, vale notar que a Lei no 6.880, de 9 de dezembro de 1980, que dispõe sobre o Estatuto dos Militares, determina, no art. 28, que estão entre os preceitos de ética militar exercer, com autoridade, eficiência e probidade, as funções que lhe couberem em decorrência do cargo (inciso II) e cumprir e fazer cumprir as leis, os regulamentos, as instruções e as ordens das autoridades competentes (inciso IV) e ser justo e imparcial no julgamento dos atos e na apreciação do mérito dos subordinados (inciso V).

Portanto, a autoridade competente para a instauração de sindicância nas Forças Armadas, atenta aos seus deveres funcionais, não poderá ignorar indícios de transgressões disciplinares ou contravenções (e, ainda, no caso específico do Exército, violações de direito) de que venha a tomar conhecimento por meio do material coletado pela Comissão Nacional da Verdade, tais como tendem a ser aqueles que apontam para o desvio de uso de bens públicos.

\section{Conclusões}

Do exposto, podemos concluir que:

(i) O desvio no uso de bens públicos poderá ensejar um prejuízo ao fim público afetado e, direta ou indiretamente, ao patrimônio público;

(ii) Com o desvio do uso, há potenciais danos aos interesses coletivos, ao patrimônio público e ao erário, sob quatro enfoques diversos: 
(a) potencial de dano ao interesse público ao qual o bem está afetado; (b) possível dano ao patrimônio público decorrente do uso indevido e eventualmente gratuito de um bem público - uso esse que não representa (pelo contrário, pode até prejudicar) o interesse público ao qual o bem está afetado; (c) possibilidade de danos e exigência de responsabilização do Estado que o novo uso pode, ele próprio, gerar; (d) possibilidade de que o novo uso, quando ilícito e reprovável, enseje danos morais ao Estado;

(iii) Os prejuízos ensejados ao patrimônio público pelo desvio do uso afetado do bem podem gerar tanto a responsabilidade do Estado perante os cidadãos e a coletividade afetados, como a responsabilidade do agente estatal perante o Estado;

(iv) Os trabalhos desenvolvidos pela Comissão Nacional da Verdade indicam que, no período compreendido entre 18 de setembro de 1946 e 5 de outubro de 1988, houve desvio no uso de bens públicos afetados às Forças Armadas, a quem cabia gerir, de forma eficiente, o patrimônio da União;

(v) Configura-se como uso ilícito de bens públicos afetados às Forças Armadas tanto sua utilização para práticas de tortura por agentes das Forças Armadas, como a permissão de seu uso para práticas de tortura conduzidas por agentes estatais outros, não vinculados às Forças Armadas;

(vi) A prática de um ilícito (uso desconforme dos bens públicos afetados às Forças Armadas) pode gerar diversos danos ao erário;

(vii) Para a averiguação do desvio de uso de bens temos que é possível tanto a instauração de processo administrativo comum, nos termos da Lei no 9.784, de 29 de janeiro de 1999, quanto a instauração de sindicâncias no âmbito das Forças Armadas.

(viii) Considerando as normas relativas à sindicância, temos que não só é possível como, sob pena de prevaricação, é devida e necessária a abertura de procedimento para a apuração dos indícios de desvios no uso dos bens públicos afetados às Forças Armadas e de eventuais responsabilidades decorrentes dos prejuízos que podem ter se verificado em função do uso desconforme;

(ix) O decurso do tempo não autoriza que se afaste o dever de instauração do procedimento de sindicância, tendo em vista a posição prevalecente no sentido da imprescritibilidade constitucional da obrigação de ressarcimento ao Estado por dano causado ao erário; 
(x) A Lei da Anistia poderá afastar somente os efeitos penais decorrentes de eventual desvio criminoso na atuação das Forças Armadas;

(xi) A identificação plena do regime jurídico incidente sobre cada um dos bens das Forças Armadas que tenham sido empregados indevidamente pelos militares só será possível após a apuração individual de cada caso, permitindo a identificação do contexto em que tal desvio se deu e das relações jurídicas (inclusive eventuais relações de comando) que ali se estabeleceram.

\section{Referências}

ARAÚJO, Edmir Netto de. Curso de direito administrativo. São Paulo: Saraiva, 2005.

JUSTEN FILHO, Marçal. Curso de direito administrativo. 9. ed. São Paulo: Revista dos Tribunais, 2013.

LAZZARINI, Álvaro. Servidores Militares. In: DALLARI, Adilson Abreu; NASCIMENTO, Carlos Valder do; MARTINS, Ives Gandra (Coord.). Tratado de direito administrativo. São Paulo: Saraiva, 2013.

MARQUES NETO, Floriano Azevedo. Bens públicos: função social e exploração econômica. O regime jurídico das utilidades públicas. Belo Horizonte: Fórum, 2009.

MEDAUAR, Odete. Direito administrativo moderno. 12. ed. São Paulo: Revista dos Tribunais, 2008.

NORONHA, Edgard Magalhães de. Direito penal. 8. ed. São Paulo: Saraiva, 1983. v. 1.

RODRIGUES, Silvio. Direito civil: parte geral. São Paulo: Saraiva, 2003. v. 1. 